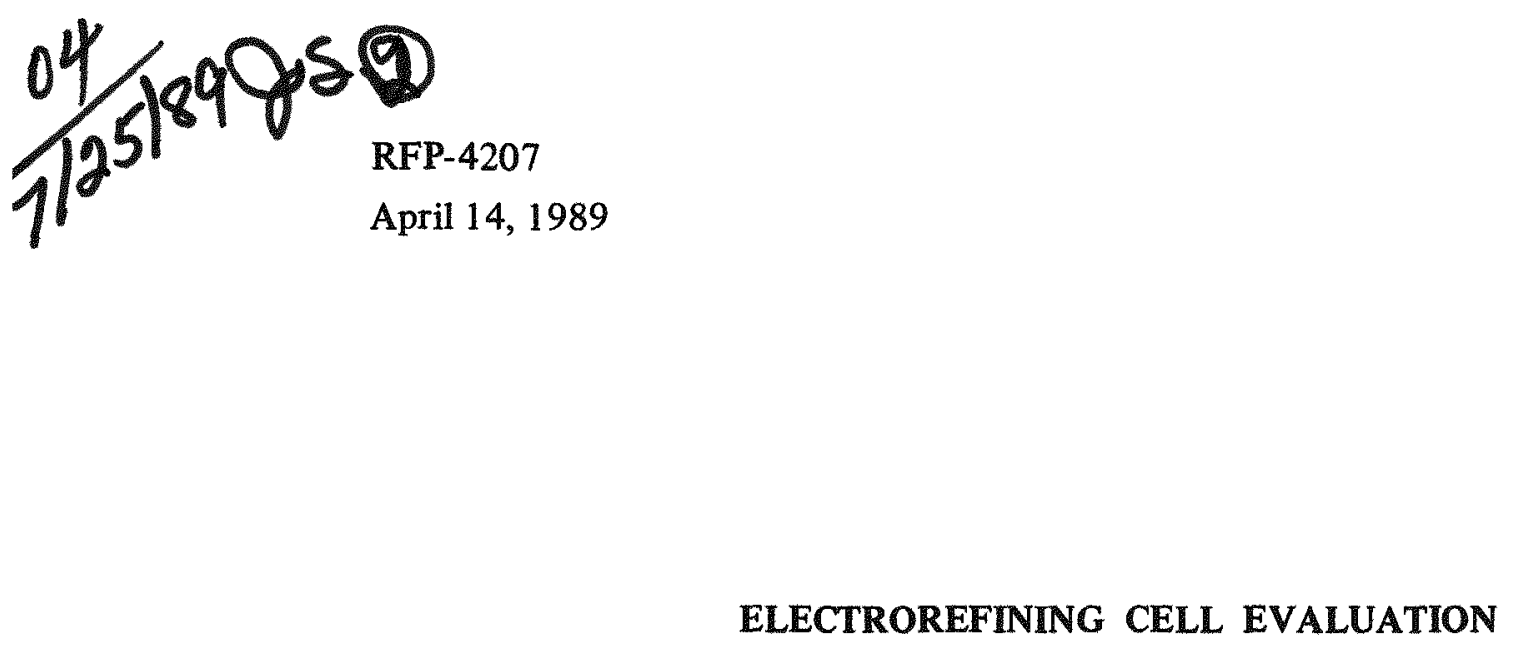

\title{
ELECTROREFINING CELL EVALUATION
}

\author{
M. C. Bronson
}

RFP-4207

April 14, 1989

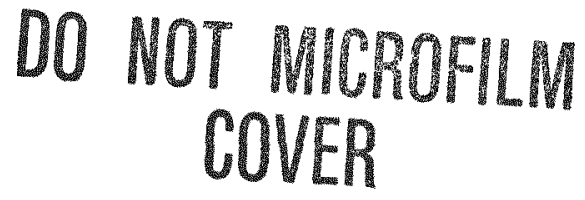

\section{Rockwell International}

\author{
Aerospace Oparations \\ Rocky Flats Plant \\ P.O. Box 464 \\ Golden, Colorado 80402-0464
}

U. S. DEPARTMENT OF ENERGY

CONTRACT DE-ACO4.76DPO3533 


\section{DISCLAIMER}

This report was prepared as an account of work sponsored by an agency of the United States Government. Neither the United States Government nor any agency Thereof, nor any of their employees, makes any warranty, express or implied, or assumes any legal liability or responsibility for the accuracy, completeness, or usefulness of any information, apparatus, product, or process disclosed, or represents that its use would not infringe privately owned rights. Reference herein to any specific commercial product, process, or service by trade name, trademark, manufacturer, or otherwise does not necessarily constitute or imply its endorsement, recommendation, or favoring by the United States Government or any agency thereof. The views and opinions of authors expressed herein do not necessarily state or reflect those of the United States Government or any agency thereof. 


\section{DISCLAIMER}

Portions of this document may be illegible in electronic image products. Images are produced from the best available original document. 


\section{DISCLAIMER}

This report was prepared as an account of work sponsored by an agency of the United States Government. Neither the United States Government nor any agency thereof, nor any of their employees, makes any warranty, express or implied, or assumes any legal liability or responsibility for the accuracy, completeness, or usefulness of any information, apparatus, product, or process disclosed, or represents that its use would not infringe privately owned rights. Reference herein to any specific commercial product, process, or service by trade name, trademark, manufacturer, or otherwise, does not necessarily constitute or imply its endorsement, recommendation, or favoring by the United States Government or any agency thereof. The views and opinions of authors expressed herein do not necessarily state or reflect those of the United States Government or any agency thereof.

This report has been reproduced directly from the best available copy.

Available to DOE and DOE contractors from the Office of Scientific and Technical Information, P. O. Box 62, Oak Ridge, TN 37831; prices available from (615) $576-8401$, FTS $626-8401$.

Available to the public from the National Technical Information Service, United States Department of Commerce, 5285 Port Royal Rd., Springfield, VA 22161.

\section{Price Codes:}

Microfiche:

Code A01

Printed Copy: 001-025 pages, Code A02

026-050 pages, Code $A 03$

051-075 pages, Code A04

076-100 pages, Code A05

101-125 pages, Code A06

\section{DO NOT MICROFILM THIS PAGE}




\title{
ELECTROREFINING CELL EVALUATION
}

\author{
M. C. Bronson
}

\author{
R. L. Thomas, Editor
}

I. C. Delaney, Compositor

\section{DISCLAIMER}

This report was prepared as an account of work sponsored by an agency of the United States Government. Neither the United States Government nor any agency thereof, nor any of their employees, makes any warranty, express or implied, or assumes any legal liability or responsibility for the accuracy, completeness, or usefulness of any information, apparatus, product, or process disclosed, or represents that its use would not infringe privately owned rights. Reference herein to any specific commercial product, process, or service by trade name, trademark, manufacturer, or otherwise does not necessarily constitute or imply its endorsement, recommendation, or favoring by the United States Government or any agency thereof. The views and opinions of authors expressed herein do not necessarily state or reflect those of the United States Government or any agency thereof.

\section{SUBJECT DESCRIPTORS}

\section{CRAC ER Cell}

ER

Electrorefining

LANL ER Cell

Modified LANL ER Cell

ROCKWELL INTERNATIONAL

AEROSPACE OPERATIONS

ROCKY FLATS PLANT

P. O. BOX 464

GOLDEN, COLORADO 80402.0464

Prepared under Contract DE-AC04-76DPO3533

for the

Albuquerque Operations Office

U.S. Department of Energy

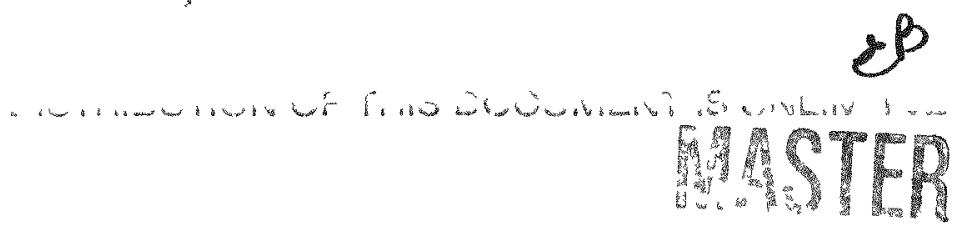


RFP-4207

\section{DO NOT MICROFILM THIS PAGE}




\section{CONTENTS}

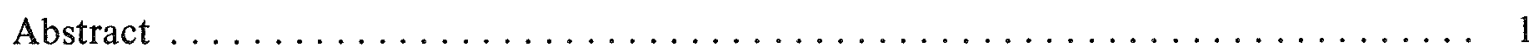

Introduction $\ldots \ldots \ldots \ldots \ldots \ldots \ldots \ldots \ldots \ldots \ldots \ldots \ldots \ldots \ldots \ldots$

Objective. ........................... 1

Background $\ldots \ldots \ldots \ldots \ldots \ldots \ldots \ldots \ldots \ldots \ldots \ldots \ldots \ldots \ldots \ldots$

Plutonium Electrorefining Basics. . . . . . . . . . . . . . . . 2

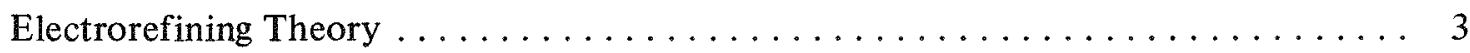

Equipment and Procedures $\ldots \ldots \ldots \ldots \ldots \ldots \ldots \ldots \ldots \ldots \ldots$

LANL Cell. ........................... 5

Modified LANL Cell $\ldots \ldots \ldots \ldots \ldots \ldots \ldots \ldots \ldots \ldots \ldots \ldots \ldots$

CRAC Cell. ........................................ 8

Operational Parameters . . . . . . . . . . . . . . . . . . . 12

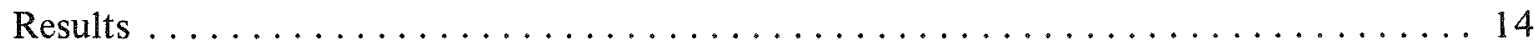

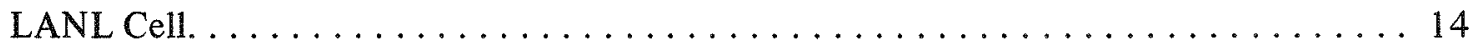

Modified LANL Cell . . . . . . . . . . . . . . . . . . . . . . . 14

CRAC Cell. . . . . . . . . . . . . . . . . 17

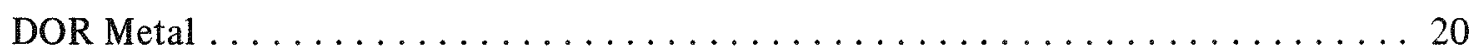

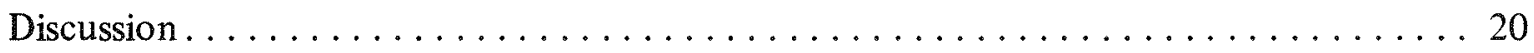

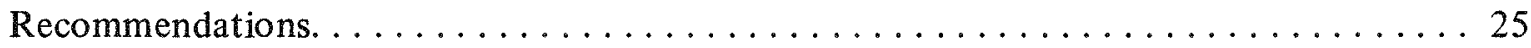

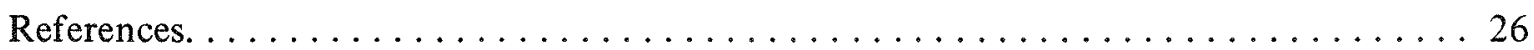


RFP-4207

\section{DO NOT MICROFILM THIS PAGE}




\section{A CKNOWLEDGMENTS}

Information and data presented in this report were obtained through the efforts of several individuals. Experimental data were obtained through assistance of R. F. Fitzpatrick, M. R. Hubbs, R. E. Giebel, C. A. Nannie, T. J. Humiston, M. A. Saba, G. T. Applegate, M. Y. Price, K. S. Lubthisophon, and D. C. Fisher. The design of the CRAC ER cell is the result of the efforts of E. Ignelzi, J. W. Berry, and J. R. Carlberg. Stirring and ceramic design support was provided by L. M. Bagaasen. The equipment used in the LANL cell evaluations was obtained from Los Alamos National Laboratory, and the CRAC cell head was provided by Mechanical Process Systems Development at Rocky Flats. Sincere thanks are expressed to these individuals, organizations, and their management for supporting this work. 
RFP-4207

\section{DO NOT MICROFILM THIS PAGE}




\section{ELECTROREFINING CELL EVALUATION}

\section{C. Bronson}

\begin{abstract}
Operational characteristics of the LANL electrorefining cell, a modified LANL electrorefining cell, and an advanced electrorefining cell (known as the CRAC cell) were determined. Average process yields achieved were: $75 \%$ for the LANL cell, $82 \%$ for the modified LANL cell, and $86 \%$ for the CRAC cell. All product metal from the LANL and modified LANL cells was within foundry specifications. Metal from one run in the CRAC cell exceeded foundry specifications for tantalum. The LANL and modified LANL cells were simple in design and operation, but product separation was more labor intensive than with the CRAC cell. The CRAC cell was more complicated in design but remained relatively simple in operation. A decision analysis concluded that the modified LANL cell was the preferred cell. It was recommended that the modified LANL cell be implemented by the Plutonium Recovery Project at Rocky Flats and that development of the CRAC cell continue.
\end{abstract}

\section{INTRODUCTION}

\section{Objective}

The objective of this work was to determine and verify the operational characteristics of the LANL electrorefining cell (designed by the Los Alamos National Laboratory), a modified LANL electrorefining cell, and an advanced Rocky Flats electrorefining cell. Once the operational characteristics were verified, the data were compared and one cell head design was recommended to the Plutonium Recovery Project at Rocky Flats for implementation. This report documents the operational characteristics of each cell and provides a cell head recommendation.

\section{Background}

The purpose of plutonium metal electrorefining (ER) is to convert impure metal to high-purity metal. In the 1960s and 1970s, Rocky Flats used stationary furnace ER cells for refining plutonium metal. ${ }^{2}$ During this period, the need for electrorefined metal was minimal and most ER was performed in development equipment. With increasing requirements for electrorefined metal, the tilt-pour furnace was adapted for ER.

Distribution of feed metal to product and residues for production tilt-pour furnace ER is shown in Figure 1. About $36 \%$ of the feed metal remains in residues, resulting in process yields of $64 \%$. The Los Alamos National Laboratory for many years utilized stationary furnaces for ER. ${ }^{2-4}$ The LANL ER cell is reported to have process yields of $82 \% .^{5}$ A task team examined existing operating equipment for ER and decided to implement stationary furnace ER in the modification of a plutonium recovery building.

Experimental programs were agreed upon for evaluating two ER cell designs: the LANL-type design and an advanced RF design. An ER cell was obtained from Los Alamos and evaluated. A cell designated as the Coaxial Removable Anode Cup (CRAC) ER cell, was designed at Rocky Flats.

FIGURE 1. Tilt-Pour ER Cell Product Distribution, Indicating $\mathrm{Pu}$ in Feed

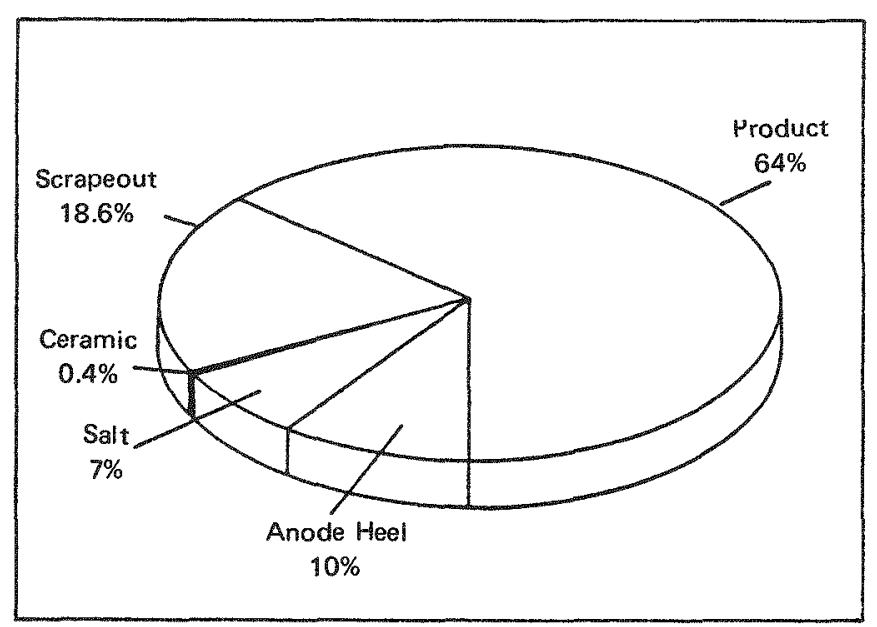


The LANL cell used in that evaluation was a $6-\mathrm{kg}$ cell with malt-mixer-type stirrer. The LANL cell was then modified and evaluated along with the CRAC cell. Modifications to the LANL cell consisted of decreasing the anode cup height to conform to the Rocky Flats $3-\mathrm{kg}$ plutonium operational limits and changing the stirrer to improve mixing in the salt phase.

\section{Plutonium Electrorefining Basics}

In plutonium ER, pure plutonium metal is produced from impure feed metal by ionic transport of the plutonium through a molten salt. Figure 2 shows a typical ER circuit connected to the LANL ER cell. Impure plutonium metal is placed in an $\mathrm{MgO}$ crucible called an anode cup and melted. The anode cup is surrounded by an equimolar $\mathrm{NaCl}-\mathrm{KCl}$ molten salt bath. To provide plutonium ions initially in the molten salt electrolyte, plutonium chloride or magnesium chloride is added. Magnesium chloride reacts with plutonium metal to produce ionic plutonium as shown by Reaction 1 . The magnesium metal vaporizes from the crucible and condenses in the colder parts of the furnace.

(Reaction 1)

$$
2 \mathrm{Pu}(\ell)+3 \mathrm{MgCl}_{2}(\ell) \rightarrow 2 \mathrm{PuCl}_{3}(\ell)+3 \mathrm{Mg}(\ell)
$$

A positive potential is applied to the liquid plutonium anode through a tantalum rod insulated in the salt phase with MgO. Plutonium oxidizes at the molten metal-salt interface in the anode cup according to Reaction 2.

$$
\mathrm{Pu}^{0} \rightarrow \mathrm{Pu}^{+3}+3 \mathrm{e}^{-}
$$

(Reaction 2)

The $\mathrm{Pu}^{+3}$ ions formed at the anode-salt interface are transported through the molten salt to the negatively charged tungsten cathode, where the plutonium is reduced back to metal by Reaction 3 .

$$
\mathrm{Pu}^{+3}+3 \mathrm{e}^{-} \rightarrow \mathrm{Pu}^{0}
$$

(Reaction 3)

Plutonium metal reduced on the tungsten cathode forms droplets on the cathode's bottom edge. These droplets fall from the cathode through the salt, forming a pool of purified metal.

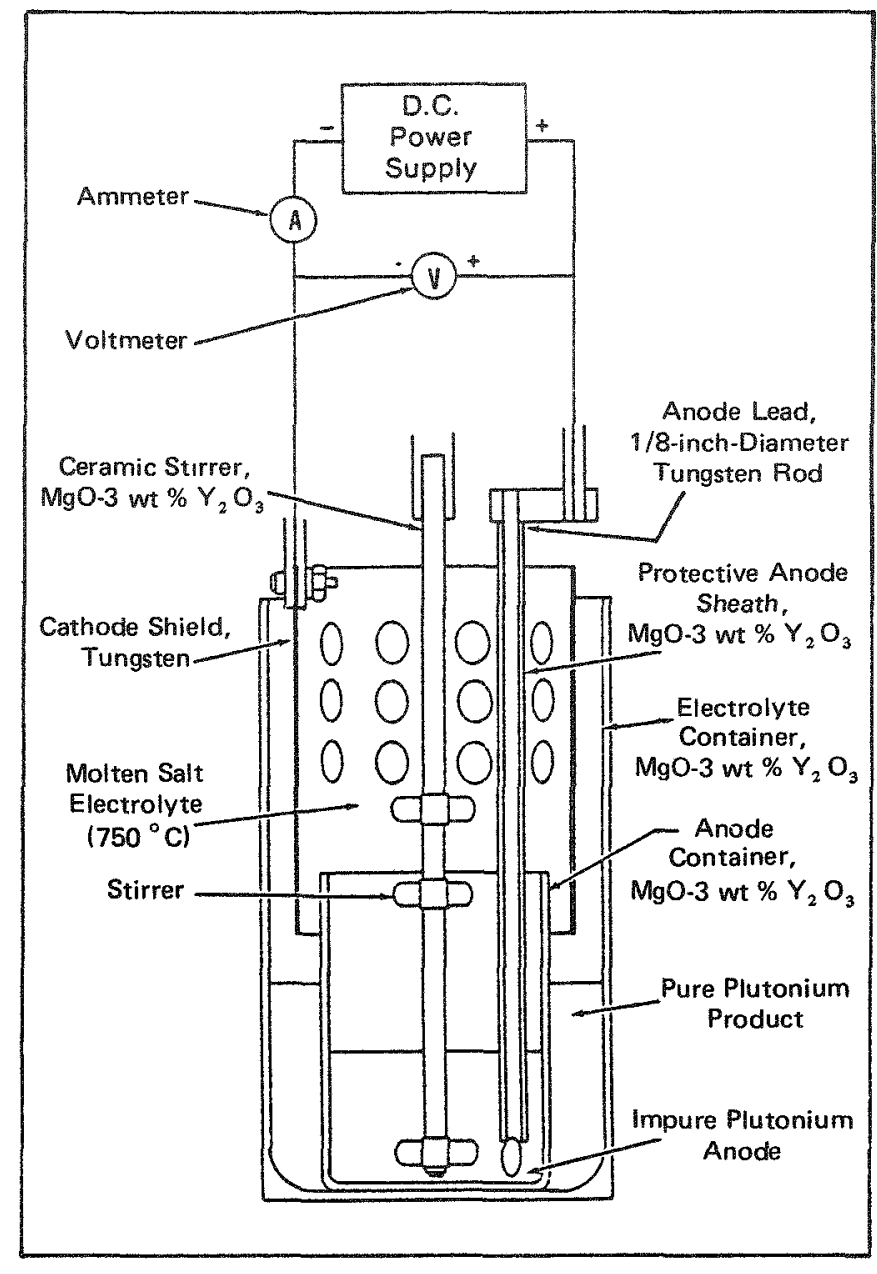

FIGURE 2. LANL ER Cell

The salt phase and the anode metal are stirred to assist the ER process. Stirring the salt increases the rate at which $\mathrm{Pu}^{3+}$ ions are mechanically transported from the anode/salt interface to the cathode and decreases the diffusion boundary layer on the cathode and anode surfaces. Stirring the molten metal ensures that a sufficient quantity of plutonium is available at the anode/salt interface, thus decreasing the oxidation of impurities. At the appropriate operating voltage, only plutonium and elements less noble (e.g., americium) are oxidized, provided there is a sufficient quantity of plutonium metal available at the anode/salt interface. As the plutonium in the anode is depleted, the concentration of impurities increases to the point that more of them begin to oxidize and transfer to the cathode. The ER run must be terminated before a significant transfer of impurities occurs. 
The method used to detect when the ER run should terminate is measurement of the ER cell potential with no external potential applied. This potential is known as back electromotive force (EMF). The back EMF is composed of two potentials: cell polarization and galvanic potential. The cell polarization is due to a plutonium concentration gradient between the anode and cathode. In a well-mixed system, this gradient consists of diffusion boundary layers at the surface of the anode and cathode. In a poorly mixed system, a concentration gradient is also present in the bulk salt phase. Cell Polarization is a non-equilibrium condition induced by the applied electrolysis potential. This potential decays rapidly (within 10 to 20 seconds) caused by stirring after interrupting the applied potential. The galvanic potential results from dissimilar metals at the anode and cathode. When the anode becomes depleted of plutonium, the composition of the anode is sufficiently different from the cathode so that the galvanic potential increases significantly. At this point, the ER run is terminated to minimize impurity carryover. It should be noted that the back-EMF measurement is taken approximately 10 seconds after the applied potential is interrupted to minimize polarization potential influence.

\section{Electrorefining Theory}

In electrorefining, the potential applied across a cell consists of several separate potentials. In general, the overall cell potential consists of the potentials given in Equation 1.

$$
\eta=\mathrm{E}+\eta_{\mathrm{a}}+\eta_{\mathrm{c}}+\mathrm{IR}+\text { Ohmic }
$$

Where:

$$
\begin{aligned}
\eta & =\text { Overall cell potential } \\
\mathrm{E} & =\text { Chemical reaction potential } \\
\eta_{\mathrm{a}} & =\text { Anodic overvoltage } \\
\eta_{\mathrm{C}} & =\text { Cathodic overvoltage } \\
\mathbb{I} & =\text { Potential across electrolyte } \\
\text { Ohmic } & =\text { Potential across electrical connections }
\end{aligned}
$$

The chemical reaction potential is a function of thermodynamic properties and is given by Equation 2, known as the Nernst equation.
(Equation 2)

Where:

$$
E=E^{0}-(R T / z F)^{*} \ln \left(\Pi a_{p} / \Pi a_{r}\right)
$$

$$
\begin{aligned}
\mathrm{E}^{0}= & \text { Chemical reaction potential at } \\
& \text { standard conditions } \\
\mathrm{R}= & \text { Ideal gas constant }(1.987 \mathrm{cal} / \text { mole } \mathrm{K}) \\
\mathrm{T}= & \text { Temperature }(\mathrm{K}) \\
\mathrm{z}= & \text { Valence } \\
\mathrm{F}= & \text { Faraday constant }(23059 \mathrm{cal} / \text { mole } \\
& \text { volt }) \\
\Pi_{\mathrm{p}}= & \text { Product of activities of products } \\
\Pi_{\mathrm{r}}= & \text { Product of activities of reactants }
\end{aligned}
$$

The chemical reaction potential at standard conditions can be calculated from the Free Energy of Reaction $\left(\Delta G^{0}\right)$ by Equation 3 .

$$
\mathrm{E}^{0}=-\Delta \mathrm{G}^{0} / \mathrm{zF}
$$

Equations 2 and 3 were used to calculate reaction potentials for plutonium ER under various conditions. Results of these calculations are shown in Table 1. Case A in this table consists of all reactants and products at unit activity and is included only as a reference case. Case B is probably the normal operational situation. Case $\mathrm{C}$ shows the results of significantly reducing the plutonium jon concentration. As shown in Case B, Reaction 3 , the potential to reduce sodium can be similar to the plutonium reduction potential, Reaction 1, when the plutonium ion concentration and the activity of metallic sodium are very low.

The cathodic and anodic overvoltages or polarization are caused by a concentration gradient at the surface of the anode and cathode. Between the surface of the anode and cathode and the molten salt electrolyte is a boundary layer often referred to as the double layer. In aqueous electrochemistry, the double layer is comprised of the inner Helmholtz plane (IHP) and outer Hemholtz plane (OHP). This terminology is not generally used in molten salt electrochemistry. The double layer is the result of the mass transfer boundary layer and the applied potential. The mass transfer boundary layer is the region between the electrode (anode or cathode) and bulk electrolyte (molten salt) where the concentration of reacting species (plutonium ion) is greater or less than its concentration in the bulk electrolyte. 
TABLE 1. Reaction Potentials

\begin{tabular}{l}
\multicolumn{2}{c}{ Reactions } \\
\hline Anodic \\
Cathodic \\
Overall
\end{tabular}

\begin{tabular}{|c|c|c|}
\hline \multicolumn{3}{|c|}{ Cases } \\
\hline A & B & $\mathrm{C}$ \\
\hline $\begin{array}{l}\quad \mathrm{E}^{\circ} \\
\text { All species at } \\
\text { unit activity }\end{array}$ & 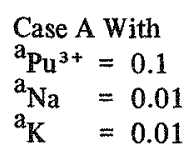 & $\begin{array}{l}\text { Case A With } \\
\mathrm{a}_{\mathrm{Pu}^{3+}}=0.01 \\
{ }^{\mathrm{a}} \mathrm{Na}=0.001 \\
\mathrm{a}_{\mathrm{K}}=0.001\end{array}$ \\
\hline
\end{tabular}

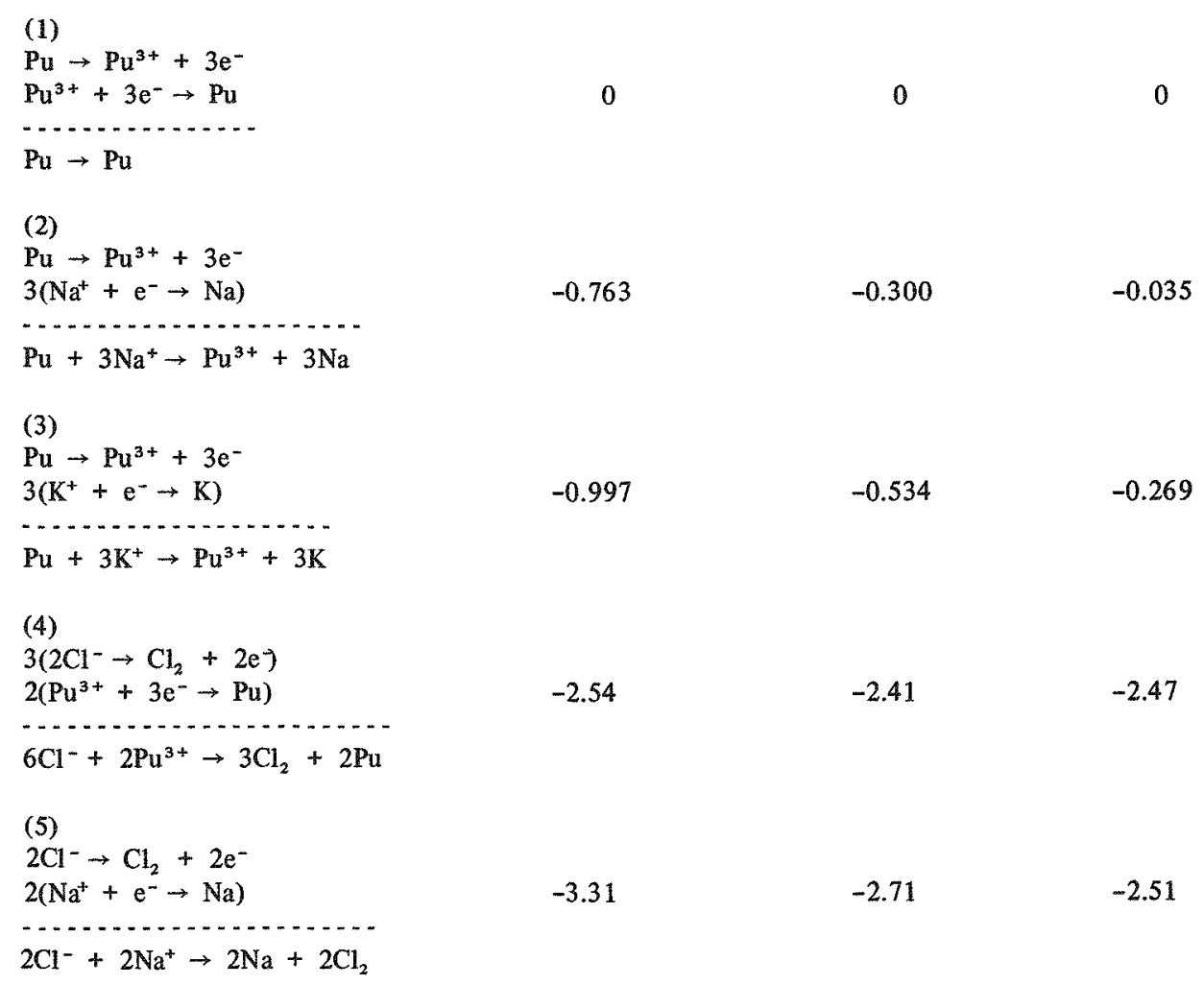

The transfer of molecules through the mass transfer boundary layer is principally diffusion controlled. The thickness of this layer is influenced by the magnitude of fluid motion in the bulk electrolyte. In the limiting case where the concentration of the reacting species (plutonium ions) approaches zero at the electrode interface (cathode), the electrolysis current density is limited by diffusion of the plutonium ions. This current density is known as the limiting current density and can be determined by Equation 4 (Reference 6).

$$
{ }^{i_{L}}=-\left(\mathrm{zFDc}^{\circ}\right) / \delta
$$

Where:

$$
\begin{aligned}
\mathrm{i}_{\mathrm{L}}= & \text { Limiting current density } \\
\mathrm{D}= & \text { Diffusion coefficient. } \\
\mathrm{c}^{\circ}= & \text { Concentration of reacting species in } \\
& \text { the bulk electrolyte. } \\
\delta \quad= & \text { Thickness of the diffusion layer. }
\end{aligned}
$$

The limiting current of an electrochemical cell can be maximized by increasing the surface area, increasing the diffusion coefficient, increasing the concentration of reacting species, or decreasing the diffusion layer. The diffusion coefficient increases with increasing temperature and the diffusion layer decreases with increased agitation. 
If the current density exceeds the limiting current density, side reactions occur. For plutonium ER in equimolar $\mathrm{NaCl}-\mathrm{KCl}$, sodium or potassium ions in the electrolyte are reduced at the cathode. The sodium or potassium may then diffuse from the cathode surface through the mass transfer boundary layer reacting with plutonium ions by Reaction 4 .

$$
\mathrm{Pu}^{3+}+3 \mathrm{Na} \rightarrow \mathrm{Pu}^{0}+3 \mathrm{Na}^{+} \quad(\text { Reaction } 4)
$$

This reaction can further limit the concentration of plutonium ions available at the cathode surface, thus perpetuating this situation. With adequate stirring, the cathodic mass transfer boundary layer can be minimized and the potential for this reaction reduced significantly. Increasing the plutonium ion concentration is another way to reduce cathodic polarization at a given applied potential.

The potential across the electrolyte, commonly called the IR drop, is the potential drop due to the resistance of the molten salt and is thus equal to the salt resistance times the current (IR). In the LANL ER cell, this resistance is typically $0.1 \mathrm{ohm}$; therefore, at 50 amps, the IR drop is 5 volts.
Figure 3 shows the cell voltage versus amperage for the LANL cell. The linearity is attributed to the IR drop across the electrolyte. The potential drop due to IR generally accounts for most of the cell potential in plutonium electrorefining and thus tends to overshadow the other potentials. In large electrolysis plants, extensive efforts are undertaken to minimize IR drop, thus conserving electrical consumption. This is principally accomplished through increasing conductivity of the electroly te and spacing the electrodes as closely as possible.

The ohmic potential is the potential drop between the potential measuring device and the electrode surface. This potential is generally minimized through cell design (i.e., anode and cathode rods of sufficient diameter). Therefore, under normal operation, it is not significant.

\section{EQUIPMENT AND PROCEDURES}

\section{LANL Cell}

The LANL ER cell (Figure 4) is a patented design? used at Los Alamos since the early 1960s. The cell

FIGURE 3. Voltage-Amperage Relationship in Plutonium ER, LANL Cell

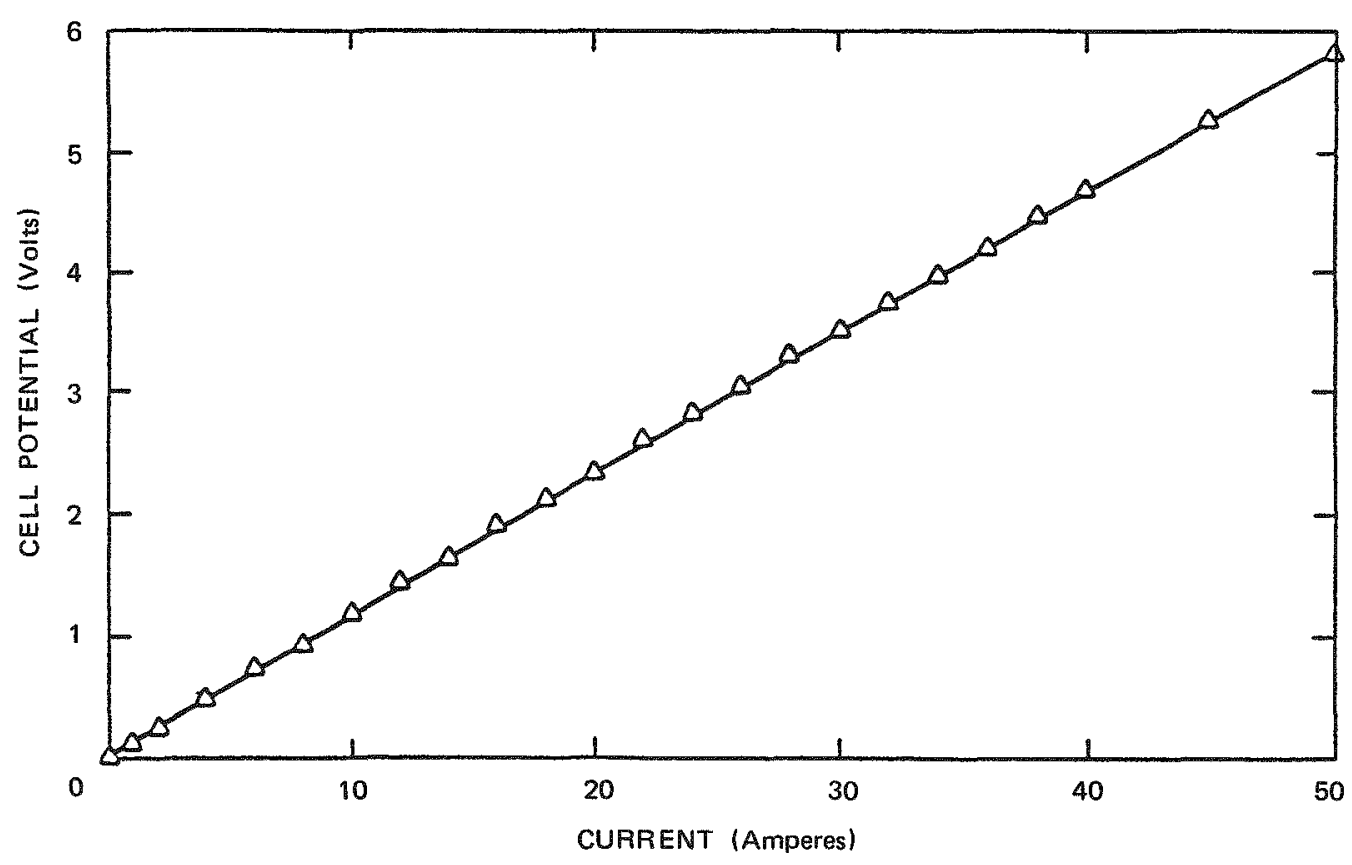




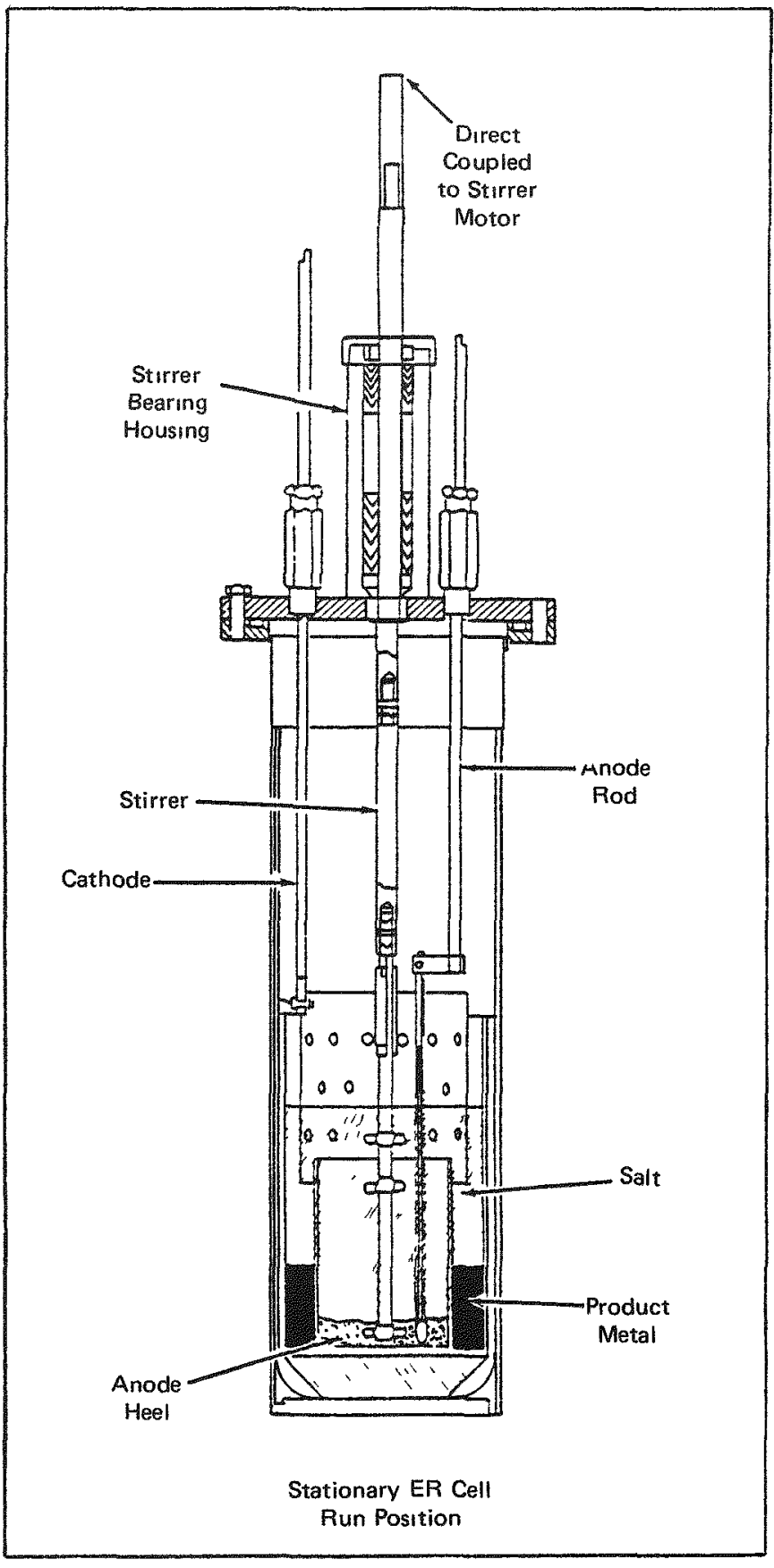

FIGURE 4. LANL ER Cell as Operated at Los Alamos

containment consists of a 23-inch-deep by 5-13/16inch o.d. Inconel well, with an 8-inch-diameter stainless steel lid. The lid, shown in Figure 5, contains a pass-through for the stirrer, anode rod, and cathode rod and a joint vacuum-argon connection. The well is surrounded by a 6 -inch i.d. by 16-inch-high resistance furnace. A vitrified magnesium

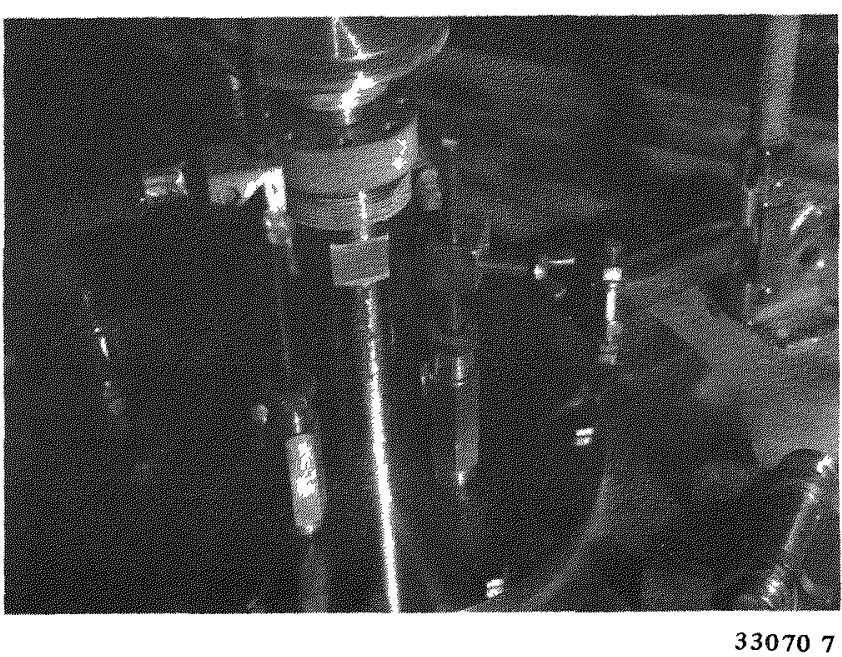

FIGURE 5. LANL Cell Lid

oxide ceramic crucible is used as the primary containment vessel. It is nested inside a tantalum safety can within a stainless steel loading can. The stainless steel loading can is next to the Inconel well. The ceramic crucible consists of a smaller (anode) cup inside a larger cup. The cathode is a hemicylinder of 20 - to 60 -mil tungsten attached to a 1/4-inch-diameter tantalum rod. The stirrer, shown in Figure 6 , is vitrified magnesium oxide coupled to a $1 / 2$-inch-diameter stainless steel rod. The stirrer is directly coupled to a $1 / 2-$ to $1-\mathrm{hp}$ variable-speed electric motor. The anode rod is 1/8-inch-diameter tungsten, electrically insulated in the salt phase by a magnesium oxide tube and dog leg coupled to a 1/4-inch-diameter stainless steel rod.

To evaluate the LANL cell at Rocky Flats, a cell head was obtained from Los Alamos and fitted to a Rocky Flats large stationary furnace well as shown in Figure 7. The Rocky Flats furnace consists of an Inconel well with a bottom section $53 / 4$ inch i.d. by 13 inches deep and a top section 8 inches i.d. by 3 inches deep. The overall well depth is 16 inches compared to an effective LANL well depth of 19 inches. This difference in well depth caused problems in adapting the LANL cell to a Rocky Flats furnace. The argon-vacuum connection to the Rocky Flats furnace is on the top section of the Inconel well. An adapter plate was fabricated because the furnace lid for the Rocky Flats furnace is 13 inches in diameter verses 8 inches for the 


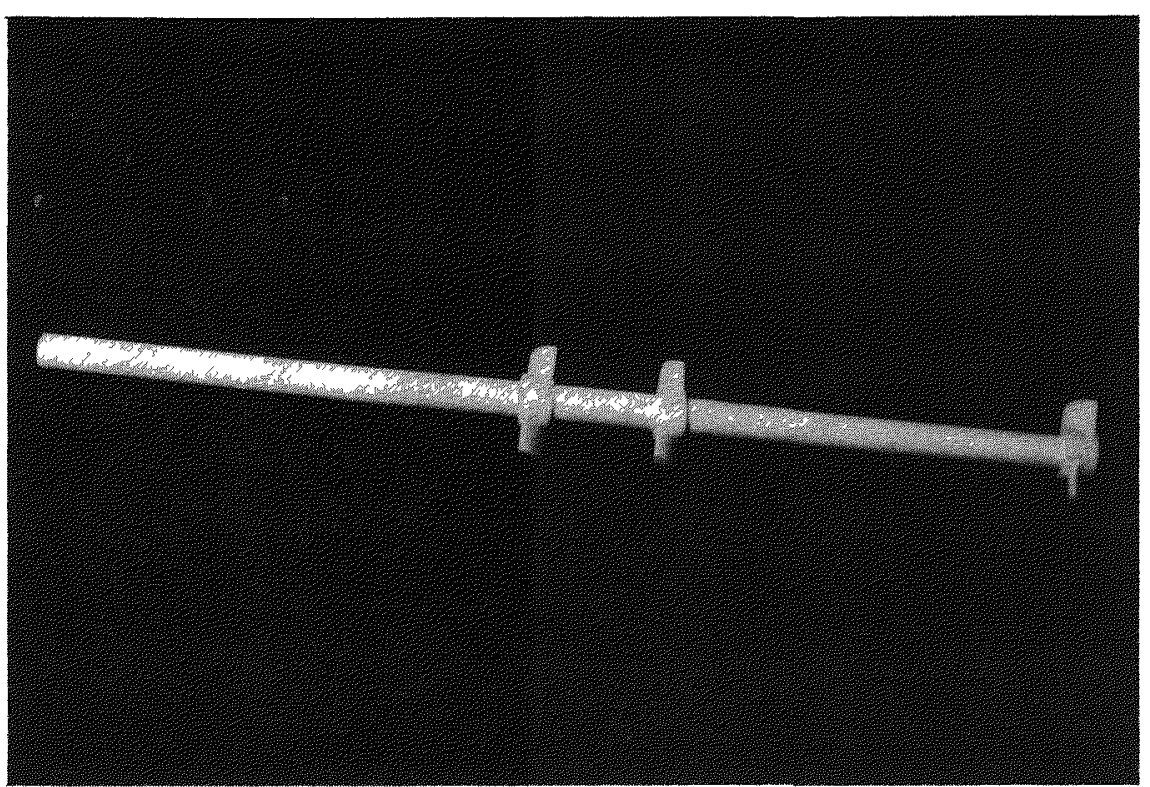

FIGURE 6. LANL ER Stirrer

FIGURE 7. LANL ER Cell as Operated at Rocky Flats

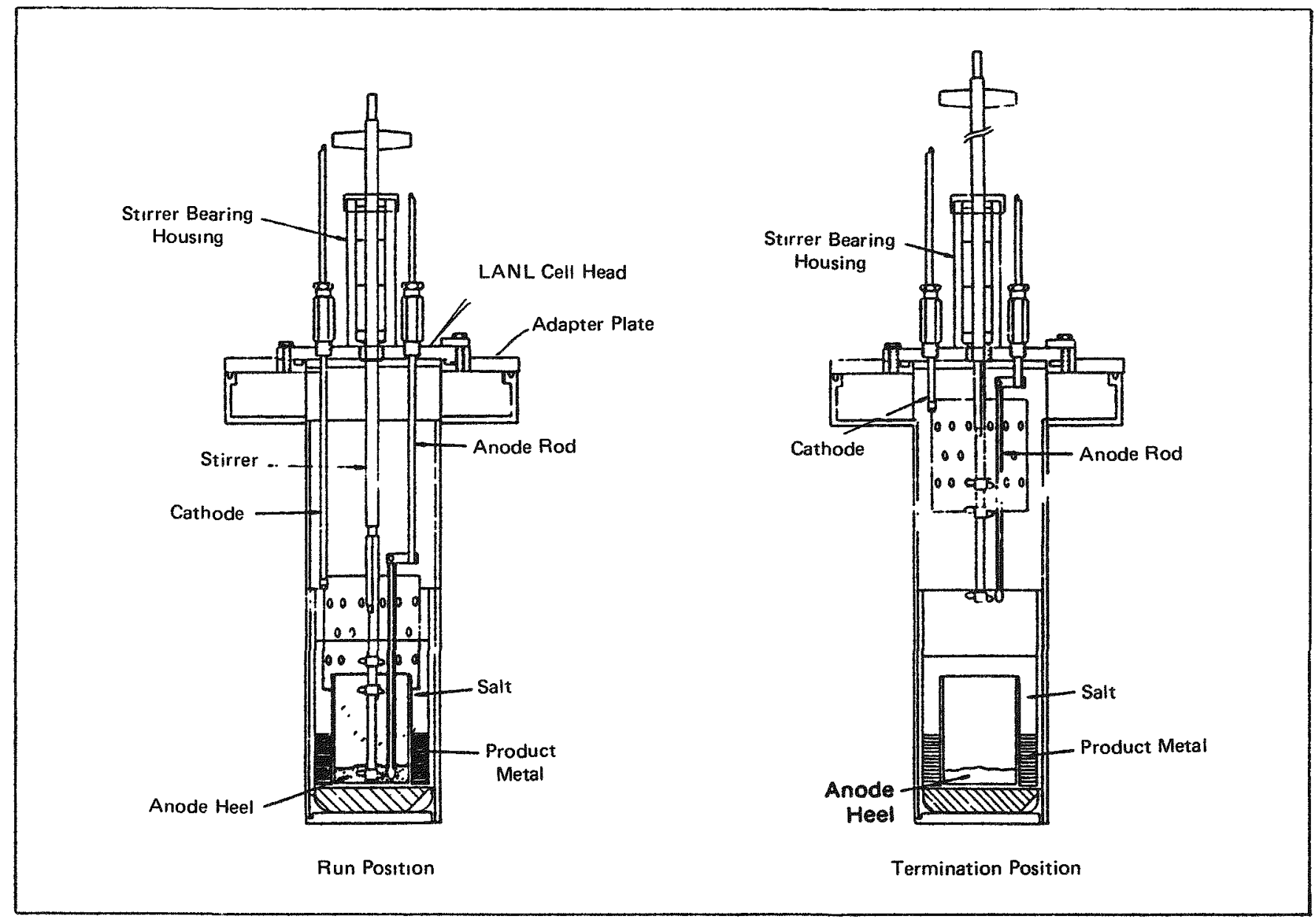




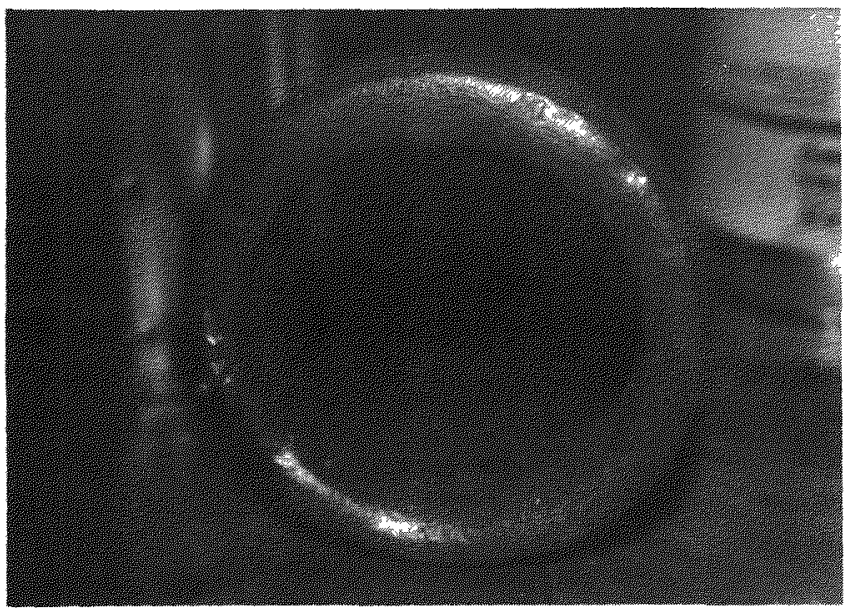

FIGURE 8. LANL Cell Product Ring

$35642-6$

LANL lid. The stirrer was connected by pulleys and an O-ring to a 1/4-hp variable-speed electric motor. During cold testing, a 1/15-hp motor, typically used at Rocky Flats, had insufficient torque to turn the stirrer because the LANL cell's Teflon seals create increased friction.

The LANL cell is loaded by placing a cylindrical ingot of impure plutonium metal into the anode cup portion of the crucible, which is then nested into the tantalum and stainless steel backup cans. A cake of $\mathrm{NaCl}-\mathrm{KCl}$ salt and loose $\mathrm{MgCl}_{2}$ salt is then placed inside the crucible. The crucible and backup cans are carefully lowered into the furnace well, and the cell head is secured. The furnace well is evacuated and backfilled with argon several times to ensure an inert operating atmosphere. The cell is then heated to operational temperature, and the stirrer, cathode, and anode are lowered into the molten salt and plutonium. Stirring is then initiated and electrolysis begins. Electrolysis is terminated when the back EMF exceeds 0.35 volts. Upon electrolysis termination, the stirrer, cathode, and anode are raised from the melt, the furnace is cooled, the crucible is removed, and the product metal and process residues are separated.

The purified plutonium product is toroidal as shown in Figure 8. To ensure that the cell maintains a good inert atmosphere, the stirrer, anode rod, and cathode rod seals are changed after every run because these rods tend to melt the Teflon seals when raised at run termination.

\section{Modified LANL Cell}

The modifications made to the LANL cell consisted of decreasing the height of the anode cup to accommodate a $3-\mathrm{kg}$ metal charge, integrating the stirrer and anode rod into a Keyed Ceramic Anode Rod Supported (KCARS) stirrer, using a graphite connector for the rotating anode rod, a positive drive (toothed) stir belt, and pulleys. Figure 9 shows the modified LANL cell, and Figure 10 shows the KCARS stirrer and cathode shield. The KCARS stirrer allows for much larger stirrer blades in the salt phase because the anode rod is out of the way, down the center of the stirrer.

Operation of this cell is similar to the LANL cell except the anode rod is positioned with the stirrer.

FIGURE 9. Modified LANL ER Cell

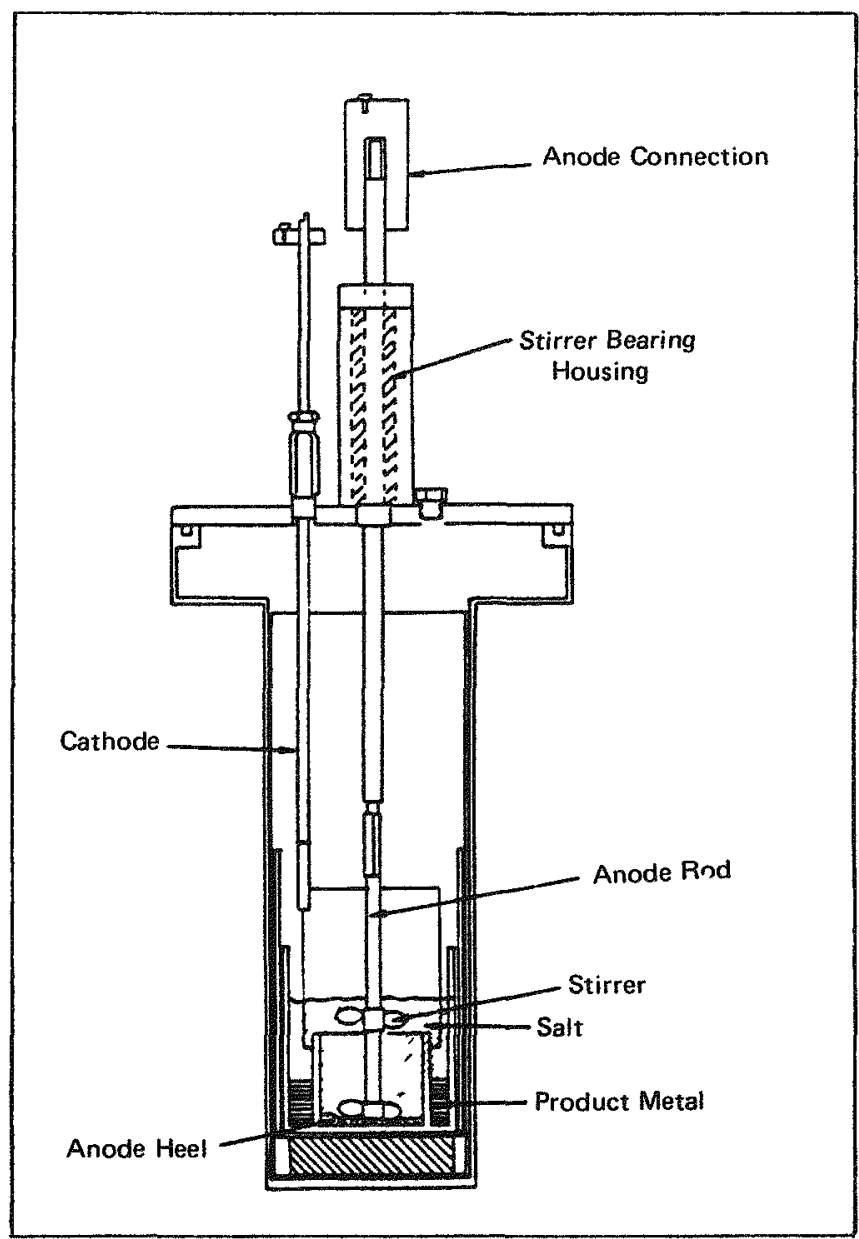




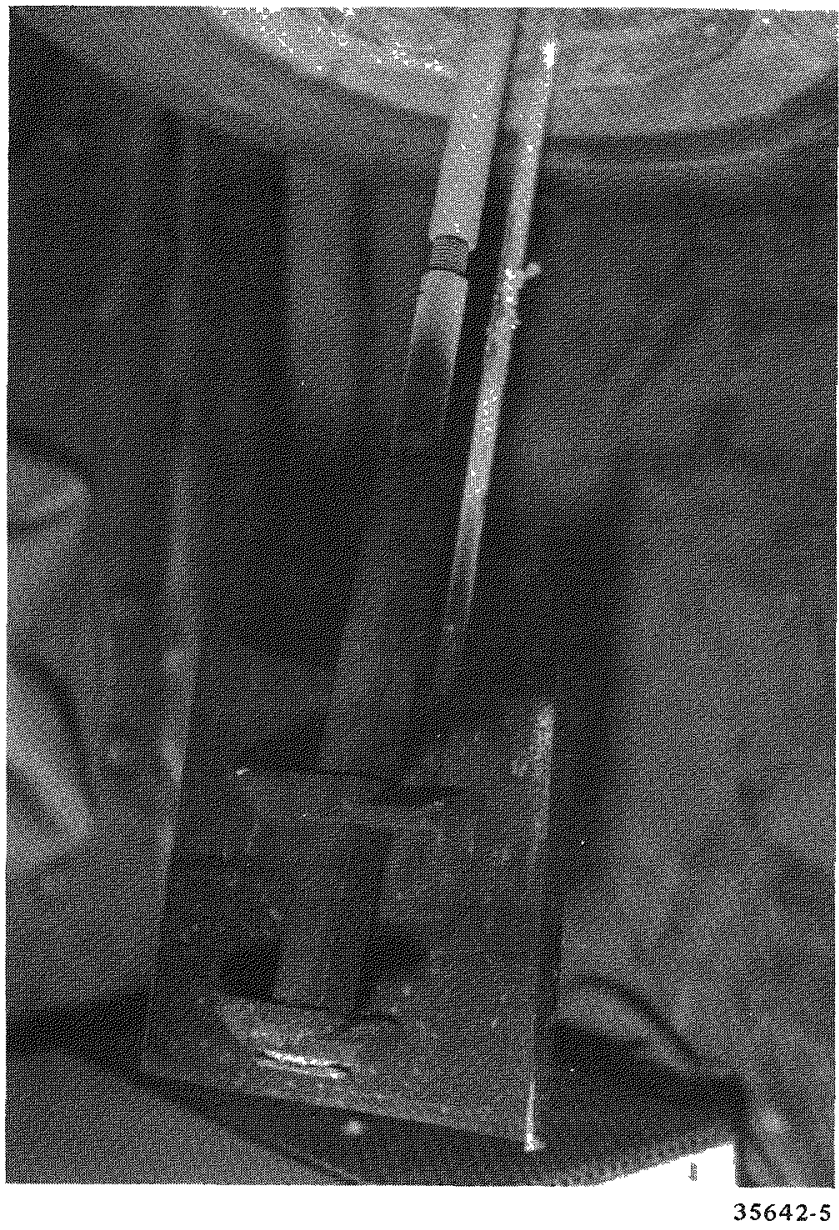

FIGURE 10. KCARS Stirrer and Cathode Shield

\section{CRAC Cell}

The CRAC cell was designed at Rocky Flats by J. W. Berry, J. R. Carlberg, and E. Ignelzi. This cell operates on the RF large stationary furnace previously described. Figure 11 shows a representation of this cell, and Figure 12 shows the cell set up for cold testing. This cell has one penetration through the cell lid for both the anode and cathode leads, which are coaxial in design. Major components are shown in Figure 13. Two stirrer types were used in this cell: a composite stirrer with a fluted ceramic bottom and upper tantalum impeller (Figure 14) and the KCARS stirrer. The vitrified magnesium oxide ceramic crucible, used as the primary containment vessel, is nested within a tantalum safety can, which is inside a stainless steel loading can, similar to that used in the LANL cell. The pertinent features of this cell are:

1. The anode cup is removable from the molten salt at the end of the ER run, thus simplifying product breakout and salt recycle.

2. The cell head is suspended from the glovebox, thus minimizing the potential for breakage of the fragile cathode and stirrer.

3. Operational simplicity is increased because the cathode and the stirrer are self-positioning. When the cathode-anode basket assembly is lowered, no operator positioning is required.

4. The design incorporates tapered ceramics, which allows the reaction products to slide from the crucible and anode cup. This provides convenient salt recycle, ceramic reuse, and simple breakouts. This is illustrated in Figures 15, 16, and 17.

5. Heat shields prevent overheating of the upper coaxial shaft. When this shaft is raised, the seals are undamaged and can be used for many runs.

6. A trough is incorporated in the bottom of the anode cup to provide for higher depletions of alpha feed metal.

The CRAC cell is loaded by placing an ingot of impure plutonium metal into the anode cup, which is set into the tantalum anode basket; the basket hangs from the cell head. A salt cake is inserted into the ceramic crucible, which is nested in the backup cans, and the cans are placed into the furnace well. The cell lid is lowered by an air cylinder and secured. The furnace well is evacuated and backfilled with argon several times to ensure an inert operating atmosphere.

The cell is then heated to operational temperature and the anode basket and cathode shield (subassembly) are lowered into the molten salt and plutonium. When the plutonium in the anode cup becomes molten, the stirrer is lowered, stirring is initiated, and electrolysis begins. Upon termination of electrolysis, the stirrer is raised from the anode 


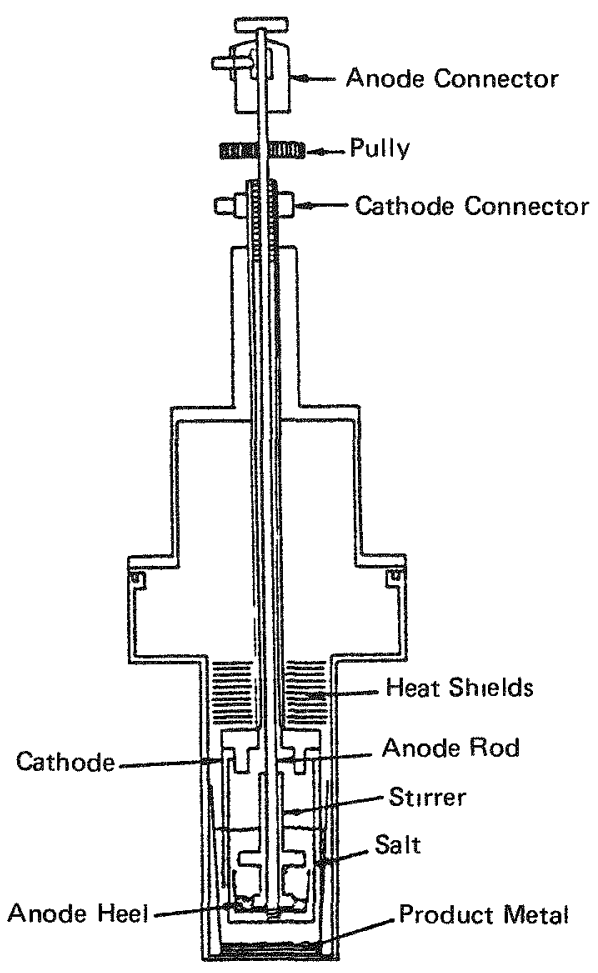

Run Position

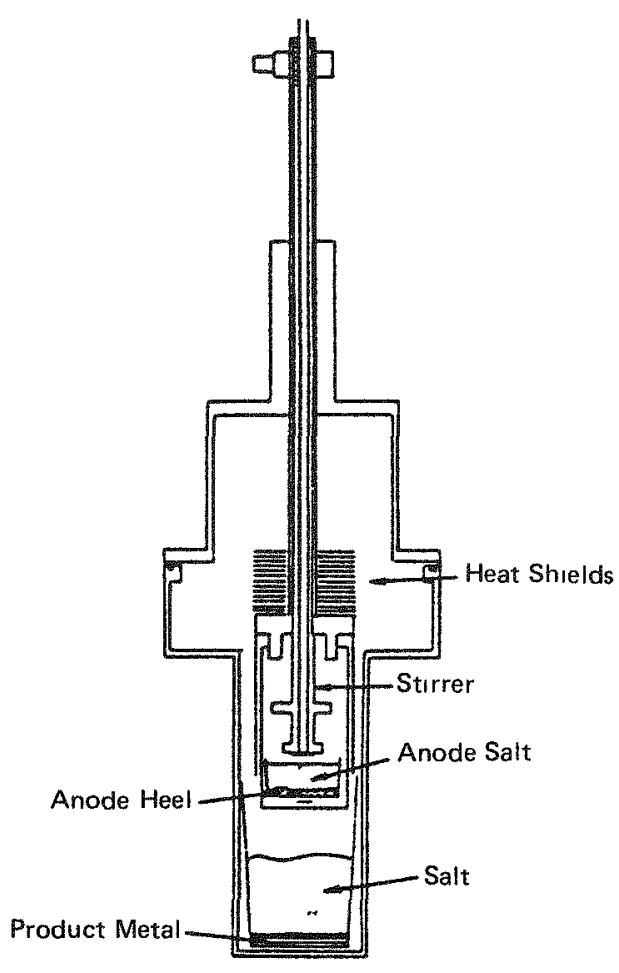

Termination Position

FIGURE 11 CRAC ER Cell

FIGURE 12. CRAC ER Cell

3441718

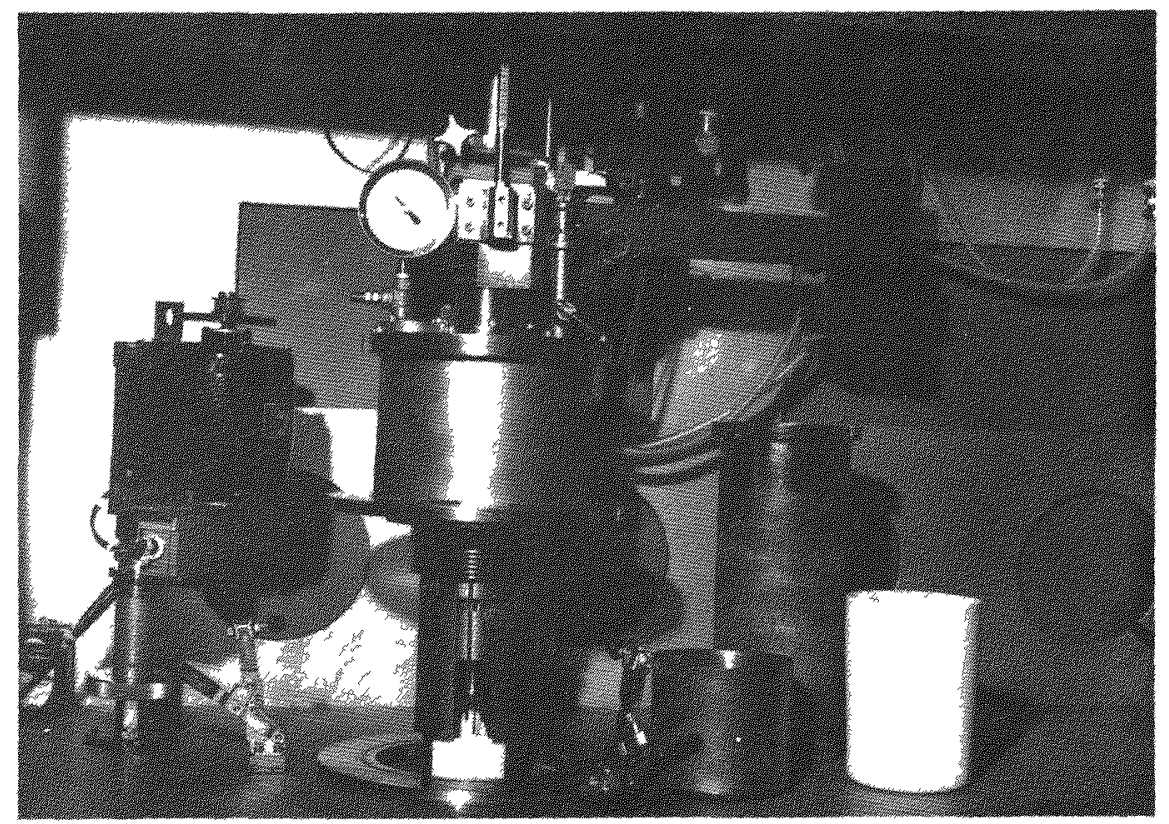




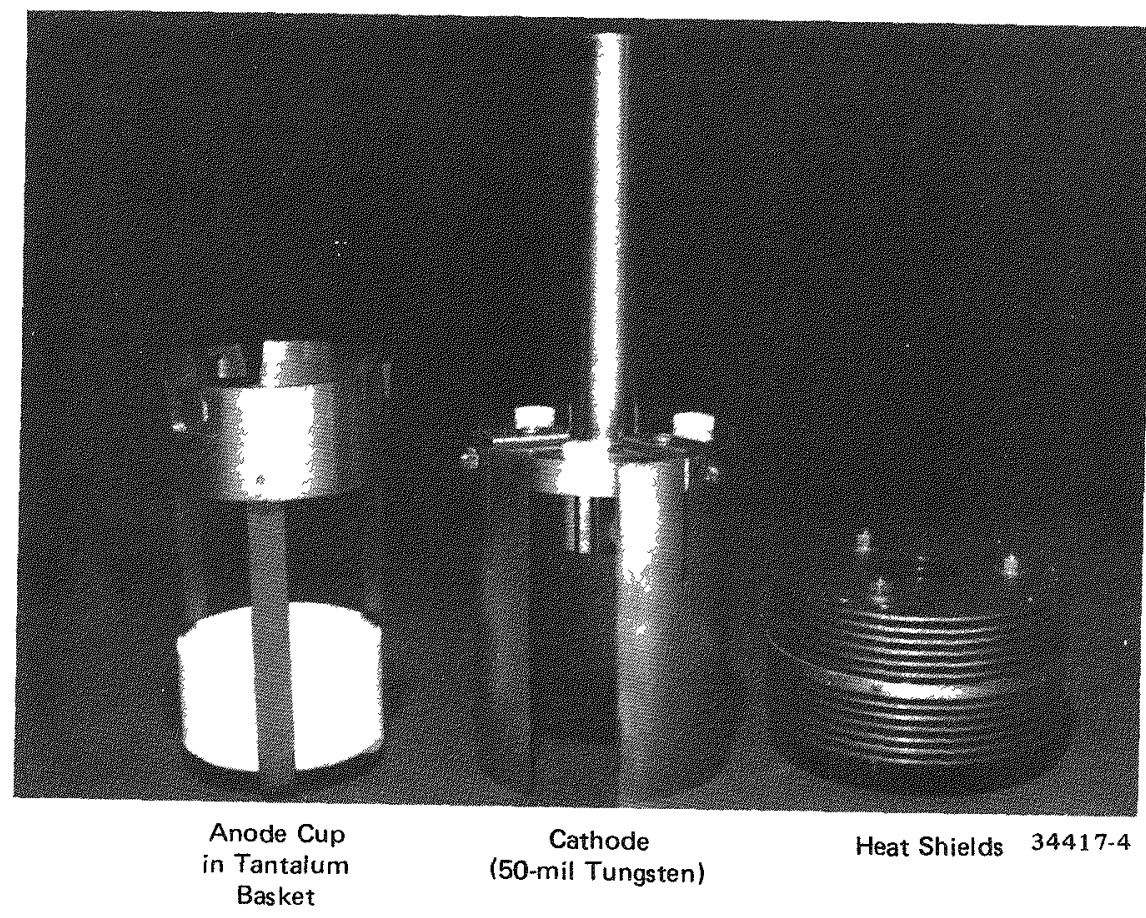

FIGURE 13. CRAC ER Cell Parts

FIGURE 14. Fluted Stirrer With Tantalum Marine Stirrer

$34537-8$

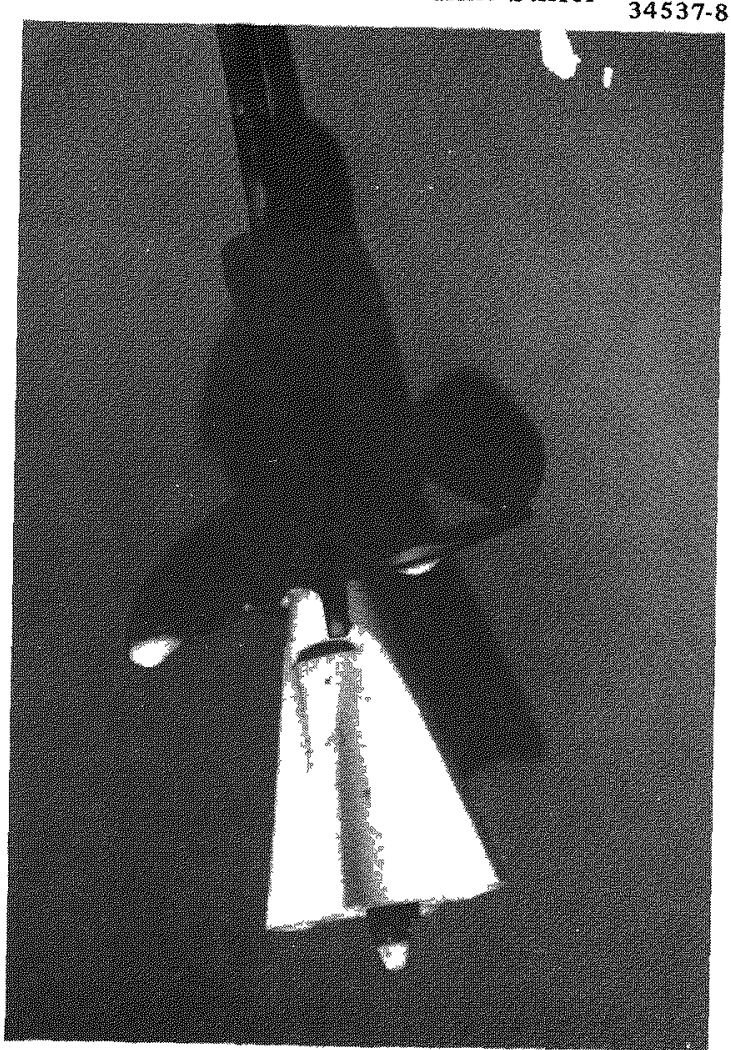




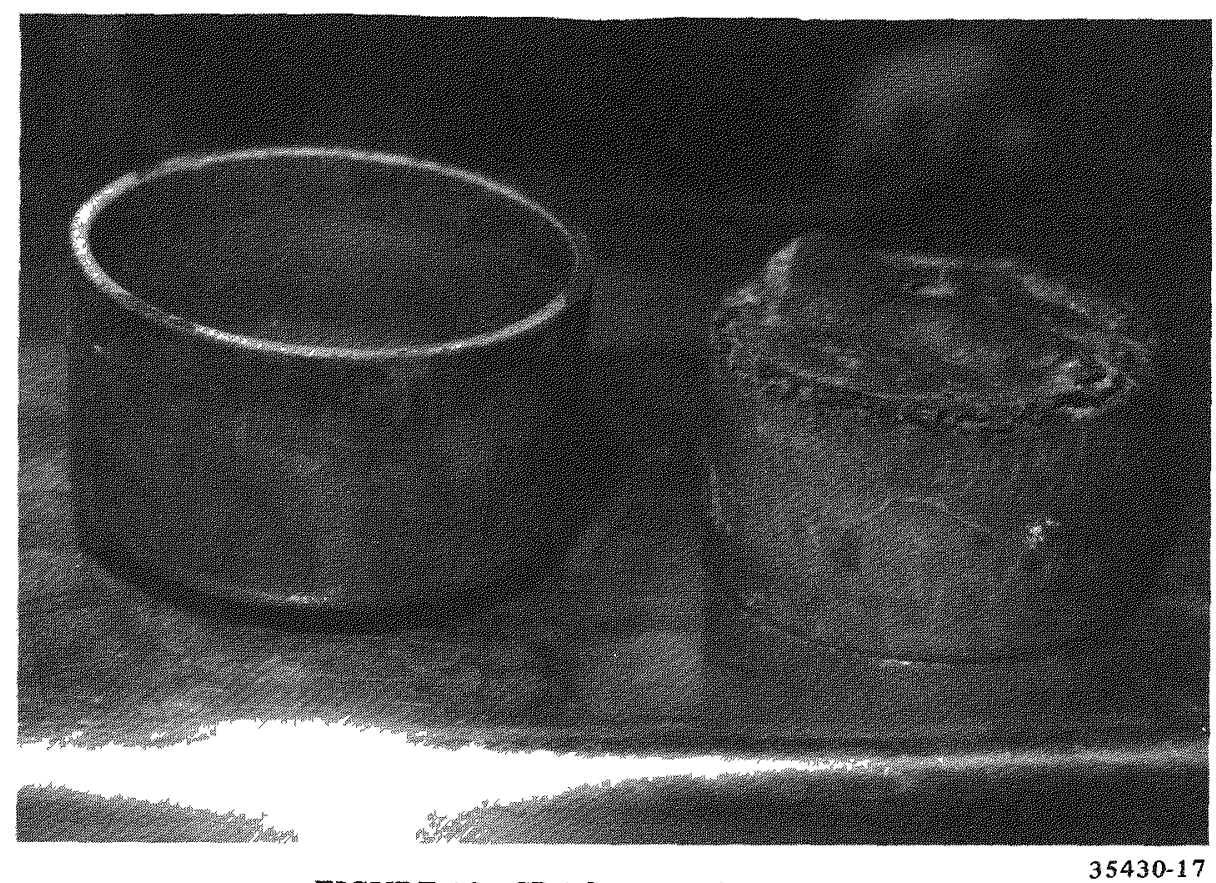

FIGURE 15. CRAC Anode Cup Breakout

35430-17

FIGURE 16. CRAC Crucible

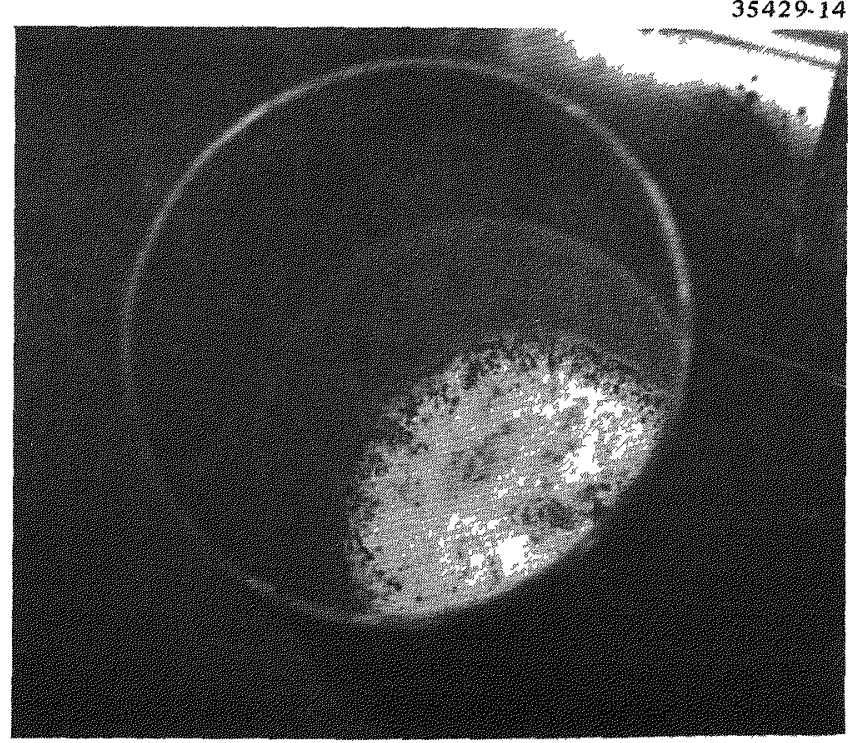

cup and the anode basket subassembly is raised from the melt. The furnace is then cooled, the crucible and anode basket are removed, and the product metal and process residues are separated. The purified product metal generated in the CRAC cell is a flat button as shown in Figure 18.
FIGURE 17. CRAC Product Metal and Salt Breakout

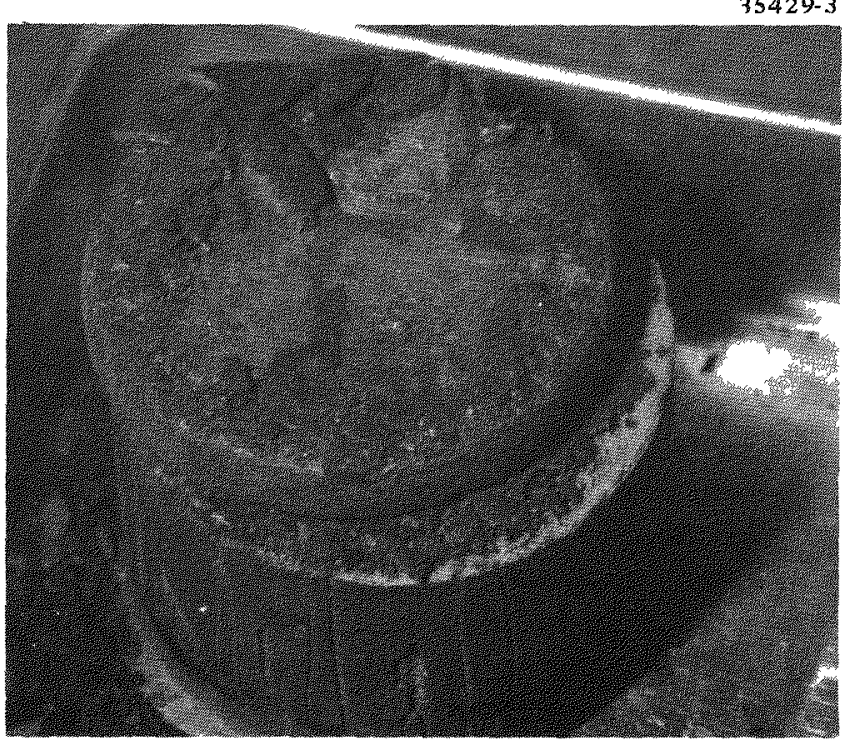

\section{OPERATIONAL PARAMETERS}

To provide meaningful ER cell comparison data, standard operating conditions and parameters were established. Deviation from these procedures were due to equipment incompatibilities or 


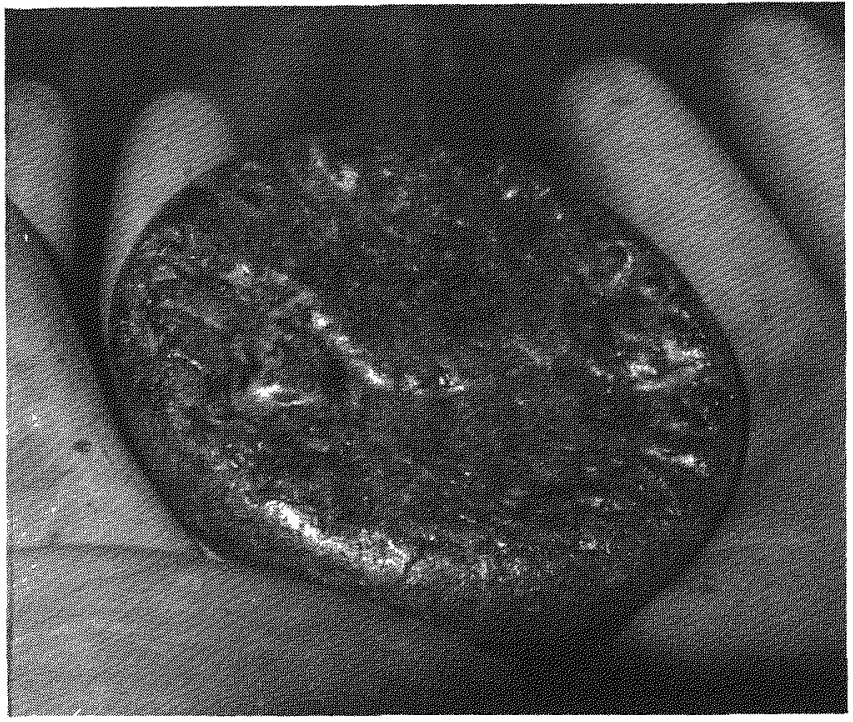

FIGURE 18. CRAC Product Metal

$35280-8$

Jutonium Recovery Project input. Table 2 contains operational parameters for each cell.

Cast buttons from hydride operations and loose alpha metal, when necessary to achieve desired charge mass, were used as feed metal in the first six runs performed in the LANL cell. Cut-up molten salt extraction product metal was used in Runs 7 and 8 . No attempt was made to maintain a standard gallium content in the runs performed in the LANL cell. Because of inadequate feed metal supplies, cast neptunium-contaminated metal was used and recycled several times in evaluating the modified LANL and CRAC cells. To standardize the feed, gallium was added when necessary to achieve $1 \%$ gallium in all feed ingots used in the modified LANL and CRAC cells. Neptunium concentrations were ignored for determining product purity.

Feed ingots were cast by either static casting or drip casting. In static casting, metal pieces were placed into a ceramic crucible and heated until the metal became molten. In drip casting, the broken metal was placed into a tantalum funnel and heated over a ceramic crucible, causing the metal to melt and drip into the crucible.

The mass of equimolar $\mathrm{NaCl}-\mathrm{KCl}$ used was dependent upon cell geometry. The LANL cell required $2300 \mathrm{~g}$ of salt to accommodate the high anode cup, which was designed for a $6-\mathrm{kg}$ anode charge. With the decreased anode cup height, the

TABLE 2. Paraineters

\begin{tabular}{l}
\multicolumn{1}{c}{ Parameter } \\
\hline Feed type \\
Feed salt weight $(\mathrm{g})$ \\
Gallium in feed $(\%)$ \\
Cell amperage \\
Heat-up time \\
Glovebox atmosphere \\
Stirrer \\
Stirring speed (rpm) \\
Salt type \\
Salt use \\
MgCl ${ }_{2}$ addition $(\mathrm{g})$ \\
Cell temperature $\left({ }^{\circ} \mathrm{C}\right)$ \\
Cell atmosphere \\
Cell pressure \\
$\quad$ (mbar absolute) \\
Run termination \\
Stirring
\end{tabular}

\begin{tabular}{|c|c|c|}
\hline \multicolumn{3}{|c|}{ Cell } \\
\hline LANL & Modified LANL & CRAC \\
\hline Variable & Cast delta & Cast delta \\
\hline 2300 & 1150 & 1625 \\
\hline $1.04-0.4$ & $1.072-0.994$ & $1.12-0.998$ \\
\hline $20-30$ & 50 & 50 \\
\hline $7-16 \mathrm{hr}$ & $5 \mathrm{hr}$ & $5 \mathrm{hr}$ \\
\hline Nitrogen & Air (not dried) & Air (not dried) \\
\hline Malt mixer & KCARS & $\begin{array}{l}\text { Composite and } \\
\text { KCARS }\end{array}$ \\
\hline $600-700$ & $150-200$ & $200-250$ \\
\hline & $\begin{array}{l}\text { Cast equimolar } \\
\mathrm{KCl}-\mathrm{NaCl}\end{array}$ & $\begin{array}{l}\text { Cast equimolar } \\
\mathrm{KCl}-\mathrm{NaCl}\end{array}$ \\
\hline & $\begin{array}{l}\text { Once through } \\
\text { (no salt recycle) }\end{array}$ & $\begin{array}{l}\text { Once through } \\
\text { (no salt recycle) }\end{array}$ \\
\hline & 103 & 103 \\
\hline & 750 & 750 \\
\hline & Argon & Argon \\
\hline & $\begin{array}{l}1000-1100 \\
\quad \text { (approx. } 3 \text { psig) }\end{array}$ & $\begin{array}{l}1000-1100 \\
\quad \text { (approx. } 3 \text { psig) }\end{array}$ \\
\hline & By back EMF & By back EMF \\
\hline & $\begin{array}{l}\text { Stirring in both the } \\
\text { anode and salt }\end{array}$ & $\begin{array}{l}\text { Stirring in both the } \\
\text { anode and salt }\end{array}$ \\
\hline
\end{tabular}


modified LANL cell required $1150 \mathrm{~g}$ of salt. The CRAC cell required $1625 \mathrm{~g}$ of salt because of the suspended anode cup.

Amperage to the LANL cell was controlled at 20-30 A to duplicate Los Alamos operational practice. In addition, Los Alamos personnel advised that high amperage causes increased sodium generation, increased plutonium shot, and decreased yields. For the modified LANL and CRAC cells, operation at $50 \mathrm{~A}$ was chosen to decrease run times and standardize operational conditions.

The cell heat-up time for the LANL cell was varied from 7 to 16 hours for operational convenience. A standard heat-up time of 5 hours was selected for the modified LANL and CRAC cells. During the LANL cell evaluation, the glovebox atmosphere was nitrogen. Metallic Na-K was formed during ER and this pyrophoric metal would not oxidize completely in the nitrogen atomosphere. On one occasion when the furnace was vacuumed, residues in the vacuum bag ignited. To eliminate this problem, the glovebox atmosphere was changed to air. This provides effective $\mathrm{Na}-\mathrm{K}$ oxidation when the furnace is opened and gives a qualitative measure of $\mathrm{Na}-\mathrm{K}$ generation.

Two ER runs were performed in the modified LANL cell using direct oxide reduction (DOR) metal buttons. These buttons were produced from batch peroxide precipitated oxide and continuous peroxide precipitated oxide.

\section{RESULTS}

\section{LANL Cell}

Table 3 gives the feed and product metal compositions for seven of the eight runs performed in the LANL cell. Run 5 is not shown; it failed because of anode cup breakage before ER could be started. Typically, the top of the metal ring was sampled with no attempt to discard the surface metal. If an assay deviated from foundry specifications (Table 4), a second sample was taken. Table 5 gives plutonium distribution data.

An important trait of the LANL cell is simplicity. Technicians unfamiliar with the cell were able to operate it with very little training. Parts can be quickly changed and replacements are relatively inexpensive. The major hands-on task in cell operation is product breakout. Approximately 45 minutes to one hour is required to separate the product metal from all residues and prepare them for shipment. At Los Alamos, it is routinely done in approximately 30 minutes.

The major operational problem with this cell stemmed from the difference in well depth between the Rocky Flats well and the Los Alamos well. Insufficient clearance was available between the top of the salt cake and the anode rod. Great care was required to position the anode rod so it would remain in the anode cup when the salt became molten. In two of the eight runs, the cell lid had to be removed when the cell was at temperature to reposition the anode rod.

The pulley-driven stirrer caused another operational problem. Friction in the stirrer seal housing required that the $\mathrm{O}$-ring stirrer belt be stretched tightly to maintain stirring. This caused frequent stirrer belt breakage and some inconsistency in run operation. The fragile nature of the stirrer and cathode is more an inconvenience than a problem; it was anticipated and replacements were readily available. However, less fragile components would enhance the LANL cell.

\section{Modified LANL Cell}

Table 6 gives the feed and product metal compositions for runs performed in the modified LANL cell under the experimental conditions. As with the LANL cell, the product metal ring was sampled from the top with no attempt to discard the surface metal. In Run ERNP04, the stirrer blades were broken, most likely during cell loading. However, because of the KCARS stirrer's keyed design, ER was performed with limited stirring. In Run ERNP08, an attempt was made to install a tantalum thermal well in the cell to measure the molten salt temperature. The stirrer hit the thermal well, breaking both the stirrer blades and thermal well. As in Run ERNP04, ER was performed with limited stirring. Table 7 gives plutonium disposition data. 
RFP-4207

TABLE 3 LANL Cell Feed and Product Assays

\begin{tabular}{|c|c|c|c|c|c|c|c|c|c|c|c|c|c|c|c|c|c|c|c|c|c|c|c|c|}
\hline \multirow[b]{2}{*}{$\begin{array}{l}\text { LANL } \\
\text { Run } \\
\text { No } \\
\end{array}$} & \multirow[b]{2}{*}{ Disposition } & \multicolumn{23}{|c|}{ (ppm unless otherwise indicated) } \\
\hline & & $\mathrm{Al}$ & $\mathrm{Am}$ & B & $\mathrm{Be}$ & $\mathrm{C}$ & $\mathrm{Ca}$ & $\mathrm{Cr}$ & $\mathrm{Cu}$ & $\mathrm{Fe}$ & $(\%)$ & $\mathrm{Mg}$ & $\mathrm{Mn}$ & Mo & $\mathrm{N}_{1}$ & $\mathrm{~Pb}$ & $\begin{array}{c}\mathrm{Pu} \\
(\mathrm{gm} / \\
\mathrm{gm}) \\
\end{array}$ & Si & Sn & $\mathrm{Ta}$ & $\mathrm{T} 1$ & $\mathrm{U}$ & W & $\mathrm{Zr}$ \\
\hline \multirow[t]{2}{*}{01} & I eed & 73 & 424 & 1 & 1700 & 50 & 7 & 1000 & 17 & 365 & 0752 & 5 & 7 & 5 & 88 & 6 & 09903 & 50 & 14 & 10 & 7 & 176 & 10 & 10 \\
\hline & Product & 50 & 43 & 1 & 050 & 50 & 5 & 50 & 10 & 10 & 0002 & 25 & 5 & 5 & 10 & 2 & 09995 & 100 & 10 & 10 & 5 & 4 & 200 & 10 \\
\hline \multirow{2}{*}{02} & $\begin{array}{l}\text { Product } \\
\text { Assay } 2\end{array}$ & 25 & 47 & 1 & 010 & 102 & 5 & 5 & 5 & 10 & 0002 & 25 & 5 & 5 & 10 & 2 & 09997 & 25 & 10 & 10 & 5 & 2 & 100 & 10 \\
\hline & $\begin{array}{l}\text { Produce } \\
\text { Average }\end{array}$ & 63 & 46 & 1 & 010 & 109 & 5 & 5 & 5 & 10 & 0002 & 25 & 5 & 5 & 10 & 2 & 09996 & 25 & 10 & 10 & 5 & 87 & 100 & 10 \\
\hline 03 & $\begin{array}{l}\text { Product } \\
\text { Average }\end{array}$ & 30 & 55 & 1 & 010 & 42 & 5 & 8 & 5 & 17 & 0002 & 63 & 5 & 5 & 17 & 2 & 09992 & 10 & 5 & 10 & 10 & 7 & 600 & 10 \\
\hline \multirow[t]{2}{*}{04} & Feed & 151 & 1052 & 1 & 1700 & 50 & 5 & 543 & 15 & 344 & 1004 & 5 & 15 & 5 & 127 & 2 & 09872 & 100 & 5 & 54 & 17 & 340 & 30 & 10 \\
\hline & Product & 25 & 105 & 1 & 025 & 50 & 5 & 10 & 5 & 10 & 0004 & 5 & 5 & 5 & 10 & 2 & 09998 & 10 & 5 & 10 & 10 & 14 & 10 & 10 \\
\hline \multirow[t]{4}{*}{06} & Feed & 100 & 1034 & 1 & 5100 & 58 & 8 & 528 & 25 & 285 & 1002 & 5 & 10 & 5 & 94 & 2 & 09866 & 398 & 10 & 508 & 7 & 269 & 10 & 10 \\
\hline & $\begin{array}{l}\text { Product } \\
\text { Assay } 1\end{array}$ & 43 & 1551 & 16 & 022 & 50 & 48 & 25 & 5 & 30 & 0003 & 174 & 5 & 5 & 10 & 4 & 09988 & 58 & 2 & 20 & 6 & 17 & 500 & 10 \\
\hline & $\begin{array}{l}\text { Product } \\
\text { Assay } 2\end{array}$ & 52 & 174 & 3 & 012 & 53 & 49 & 13 & 5 & 25 & 0002 & 85 & 5 & 1 & 25 & 4 & 09995 & 39 & 6 & 10 & 40 & 19 & 50 & 10 \\
\hline & $\begin{array}{l}\text { Product } \\
\text { Average }\end{array}$ & 48 & 1651 & & 017 & 52 & 49 & 19 & 5 & 28 & 0002 & 130 & 5 & 3 & 18 & 4 & 09992 & 49 & 4 & 15 & 23 & 18 & 275 & 10 \\
\hline \multirow{2}{*}{08} & $\begin{array}{l}\text { Product } \\
\text { Assay } 2\end{array}$ & 5 & 324 & 1 & 010 & 45 & 5 & 10 & 5 & 28 & 0002 & 100 & 5 & 5 & 28 & 2 & 09995 & 5 & 5 & 10 & 10 & 14 & 10 & 10 \\
\hline & $\begin{array}{l}\text { Product } \\
\text { Average }\end{array}$ & 5 & 325 & 1 & 010 & 51 & 28 & 10 & 5 & 25 & 0002 & 300 & 5 & 5 & 25 & 2 & 09993 & 8 & 5 & 10 & 10 & 14 & 10 & 10 \\
\hline
\end{tabular}


TABLE 4. Foundry Specifications for Plutonium Metal

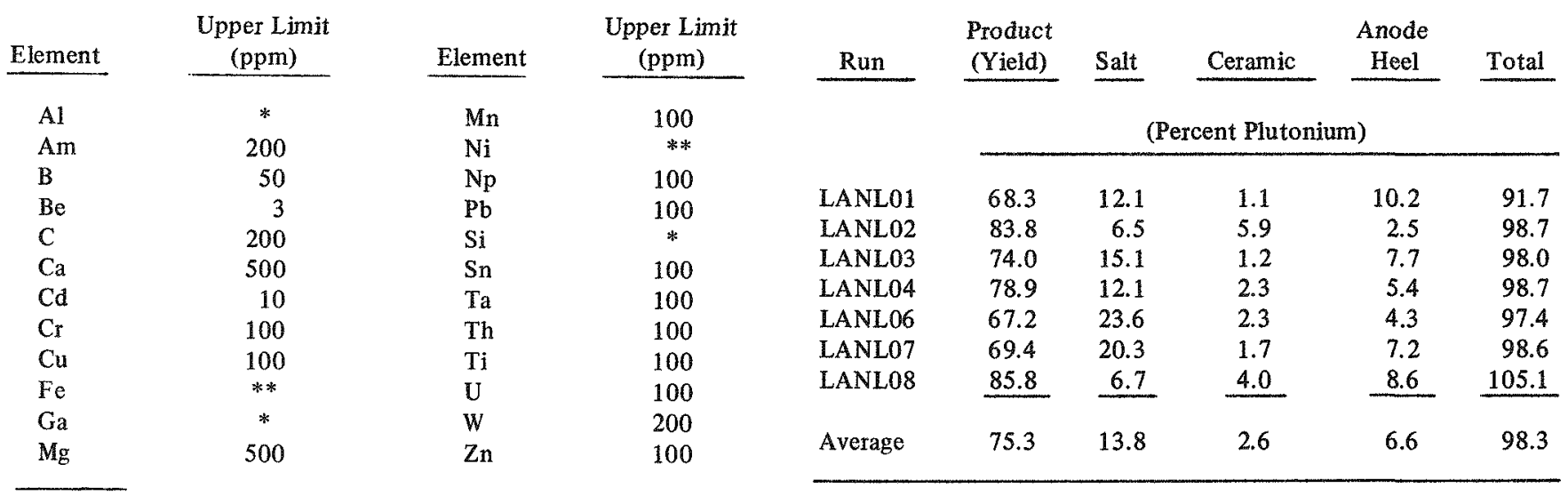

*For Ga, Al, and Si: Each button shall conform to the following limits:

$4(\mathrm{ppm} \mathrm{Ga})+10(\mathrm{ppm} \mathrm{Al})+10(\mathrm{ppm} \mathrm{Si})<1300$

**The Fe plus Ni shall be $<400$ ppm

TABLE 6. Modified LANL Cell Feed and Product Assays

(ppm, unless otherwise indicated)

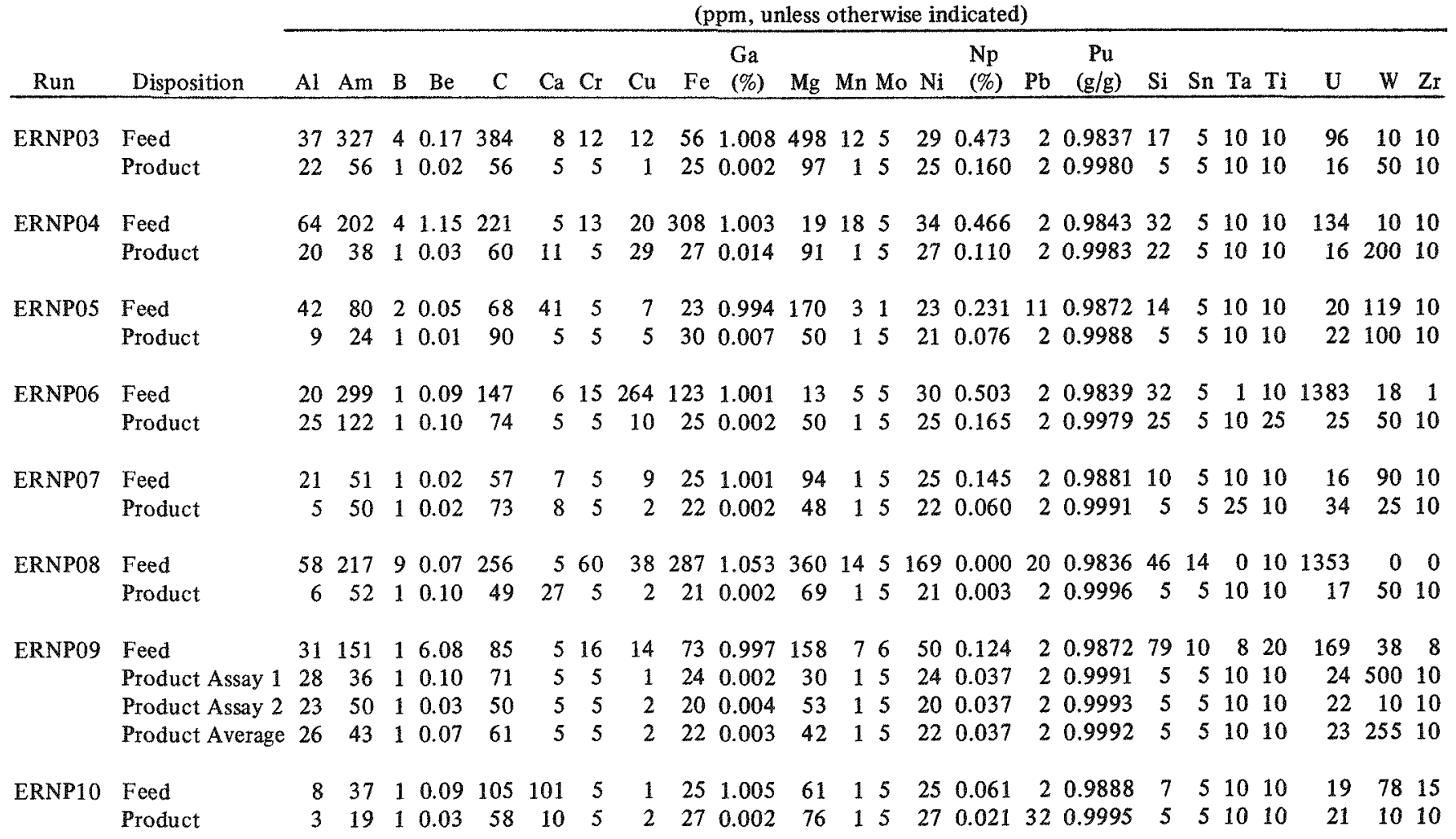


TABLE 7. Modified LANL Cell Plutonium Distribution

\begin{tabular}{|c|c|c|c|c|c|}
\hline \multirow[t]{2}{*}{ Run } & $\begin{array}{r}\text { Product } \\
\text { (Yield) }\end{array}$ & Salt & Ceramic & $\begin{array}{c}\text { Anode } \\
\text { Heel } \\
\end{array}$ & \multirow[t]{2}{*}{ Total } \\
\hline & \multicolumn{4}{|c|}{ (Percent Plutonium) } & \\
\hline ERNP03 & 79.4 & 9.4 & 3.5 & 8.3 & 100.6 \\
\hline ERNP04 & 64.4 & 18.7 & 2.2 & 14.4 & 99.8 \\
\hline ERNP05 & 83.3 & 8.0 & 3.8 & 5.2 & 100.2 \\
\hline ERNP06 & 83.0 & 8.3 & 3.2 & 5.0 & 99.5 \\
\hline ERNP07 & 79.4 & 12.6 & 2.1 & 6.2 & 100.3 \\
\hline ERNP08 & 72.2 & 12.1 & 2.2 & 10.8 & 97.3 \\
\hline ERNP09 & 84.2 & 7.8 & 2.4 & 4.7 & 99.2 \\
\hline ERNP10 & 85.4 & 6.3 & 2.8 & 6.4 & 101.0 \\
\hline Average & 78.9 & 10.4 & 2.8 & 7.6 & 99.7 \\
\hline Average* & 82.4 & 8.7 & 3.0 & 6.0 & 100.1 \\
\hline
\end{tabular}

*Excluding Runs ERNP04 and ERNP08.

The modified LANL cell is simple with operational traits similar to the LANL cell. The combined anode rod and stirrer assembly provides added simplicity because anode rod positioning is eliminated.

Product breakout was still the major timeconsuming task for hands-on operation, requiring approximately 30 minutes (less time than that for the LANL cell) mainly because of increased operator experience.

By eliminating the anode rod and decreasing anode cup height, the difference in depth between the Rocky Flats well and the Los Alamos well was no longer a major problem. The Rocky Flats furnace has a much shorter heat zone than the Los Alamos furnace, and care was required to position the stirrer within the heat zone during heatup and cooldown to avoid stirrer breakage by thermal shock. The toothed stir belt was much more reliable than $\mathrm{O}$-ring belts, but occasional belt breakage did occur. With this system, the alignment between the motor and stirrer pulleys was more critical to avoid belt breakage. The fragile nature of the cathode remained an operational inconvenience. The KCARS stirrer proved much less fragile than the malt-mixer stirrer used in the LANL cell. However, stirrer breakage periodically occurred, principally from operator handling while removing magnesium metal and other residues between runs.

\section{CRAC Cell}

Table 8 gives the feed and product metal compositions for runs performed under the given experimental conditions. Runs ERNP58, ERNP59, and ERNP62 failed and are not shown. Run ERNP58 failed from anode cup breakage. Run ERNP59 failed when the tantalum stirrer became anodic, allowing the tantalum anode basket to become anodic. This caused the tantalum basket to electrolytically dissolve at the stirrer blade level and fall into the product metal, as shown in Figure 19. In Run ERNP62, electrolysis could not be initiated, because of a magnesium metal buildup between the stirrer shaft (Figure 20) and the cathode tube (Figure 21), which caused cell shorting. Table 9 gives plutonium distribution data.

The CRAC cell demonstrated some very positive operational characteristics. Product breakout is straightforward and simple. With the tapered ceramics, contents of both the anode cup and crucible can be removed easily without ceramic breakage. Total breakout time is approximately 15 to 20 minutes. The heat shields have protected the original seals from deterioration, and they are yet to be replaced. In addition, no residues were visible in the upper portions of the cell. No $\mathrm{Na}-\mathrm{K}$ oxidation appeared when raising the cell lid after each run. Decreased handling of the cathode, attributable to the glovebox-supported cell lid, resulted in no cathode failures.

The principal operational problem with the CRAC cell has been the stirrer. The fluted ceramic bottom of the composite stirrer fractured (Figure 22) in Runs ERNP51, ERNP52, and ERNP53. Stirrer rebuilding was difficult. The tantalum upper impeller was very thin after the fourth run (ERNP54), which tends to indicate that it was shorting out to the anode. This is further substantiated by the fact that the product metal in Run ERNP53 contained excessively high tantalum levels.

The KCARS stirrer was adapted to this cell and used in Runs ERNP55, ERNP56, and ERNP57. The KCARS stirrer used in Run ERNP55 had an excessively long tantalum tip, which resulted in a larger anode heel. The tantalum tip was removed by filing, which probably stressed the attached 
TABLE 8. CRAC Cell Feed and Product Assays

(ppm, unless otherwise indicated)

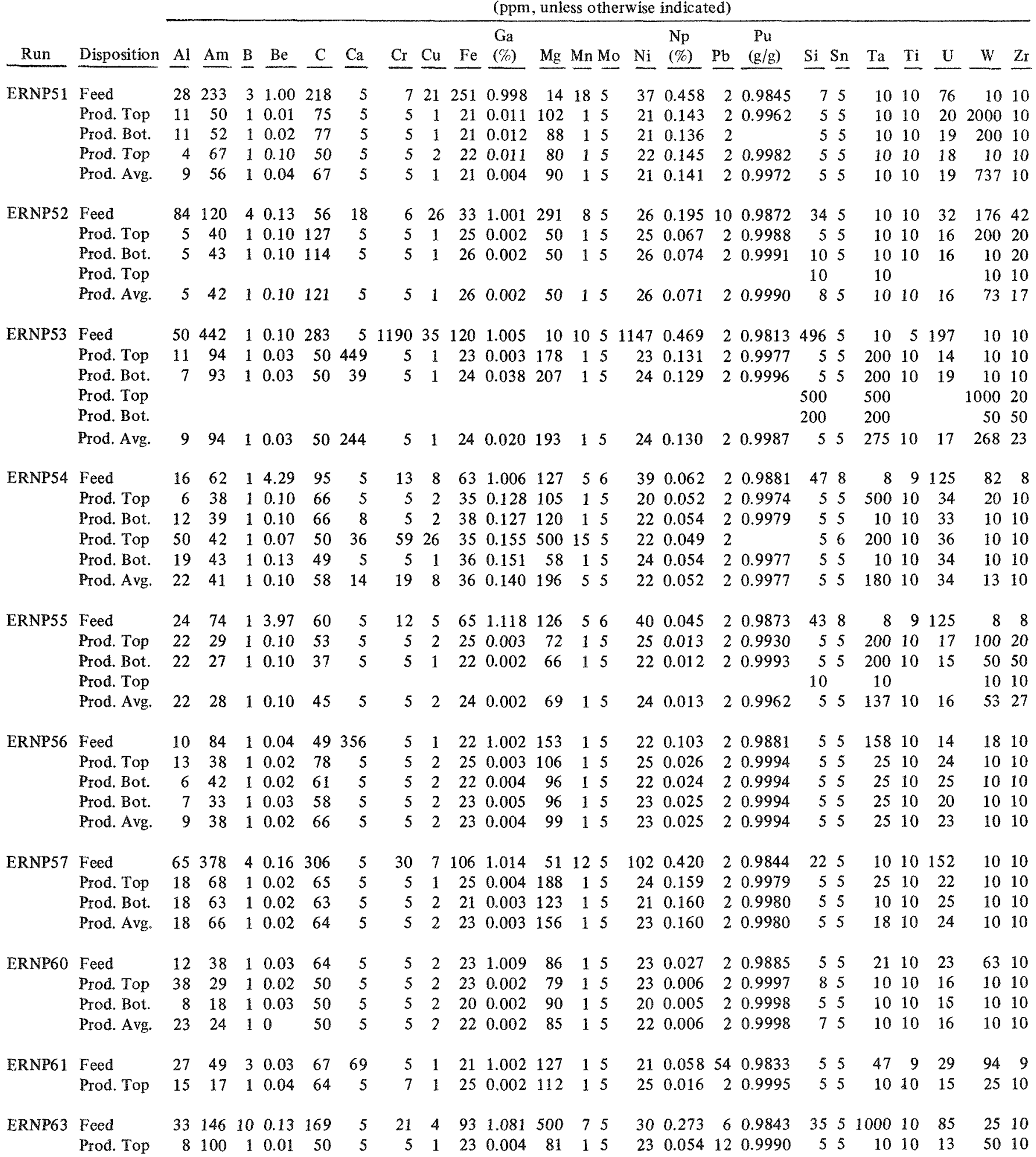




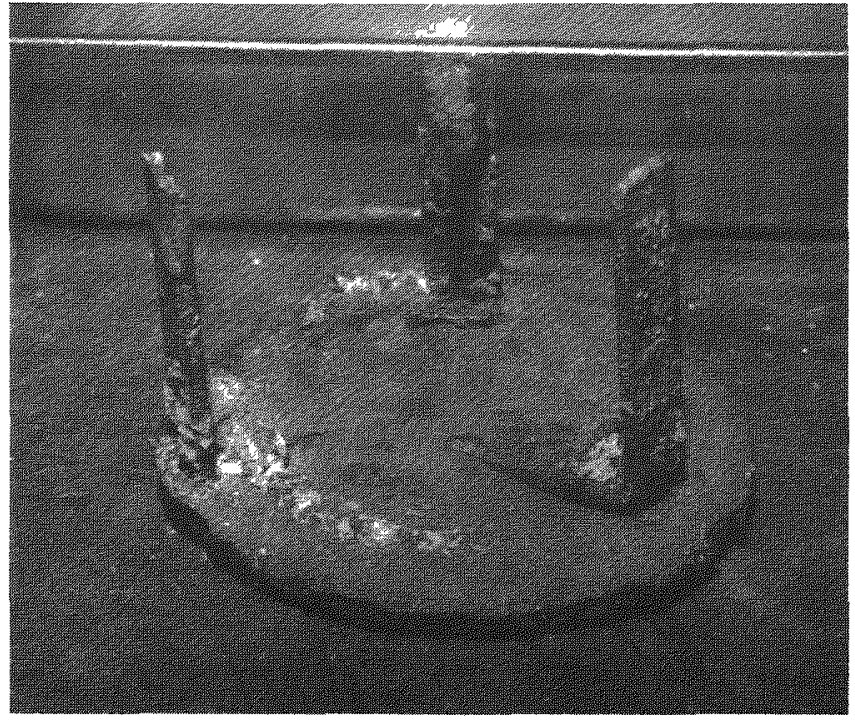

35967-14

FIGURE 19. Electrolytically Dissolved Anode Basket

FIGURE 20. Magnesium Metal on CRAC Stirrer Shaft

36120-2

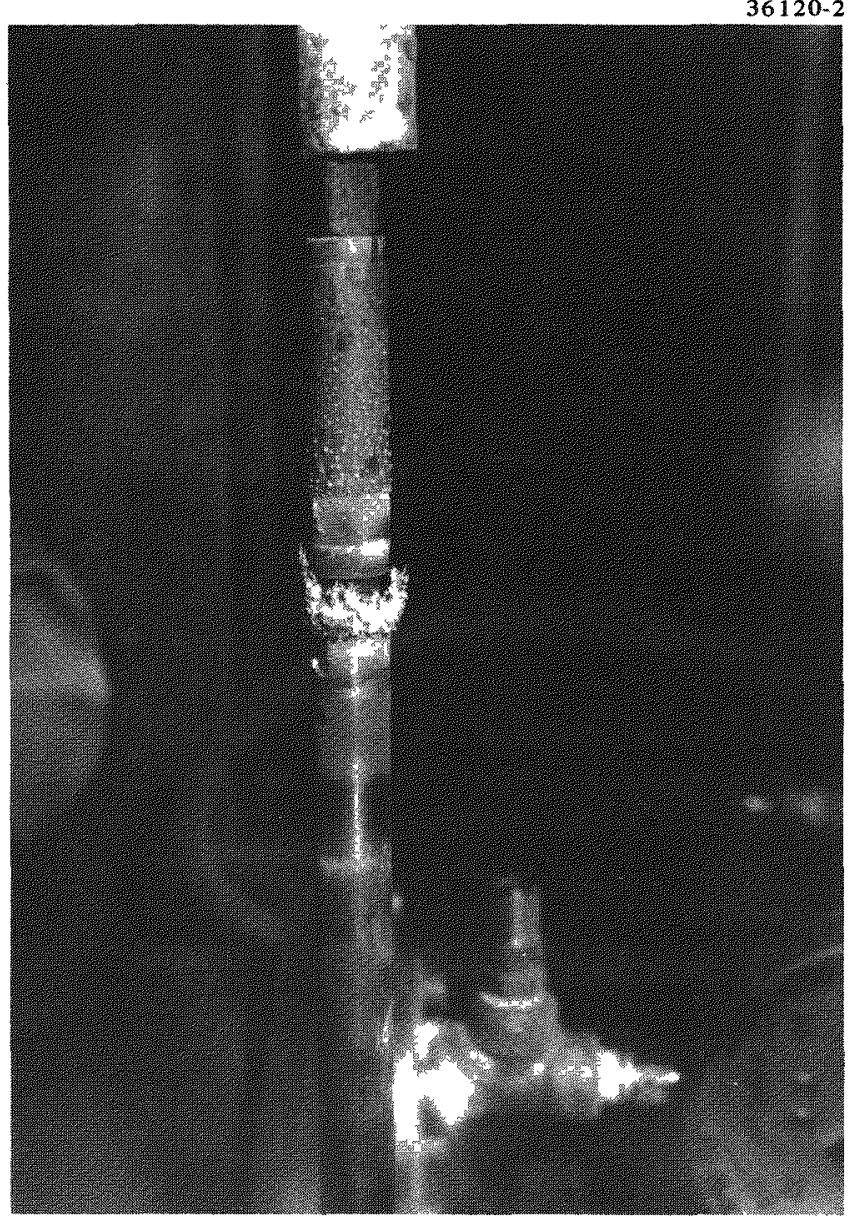

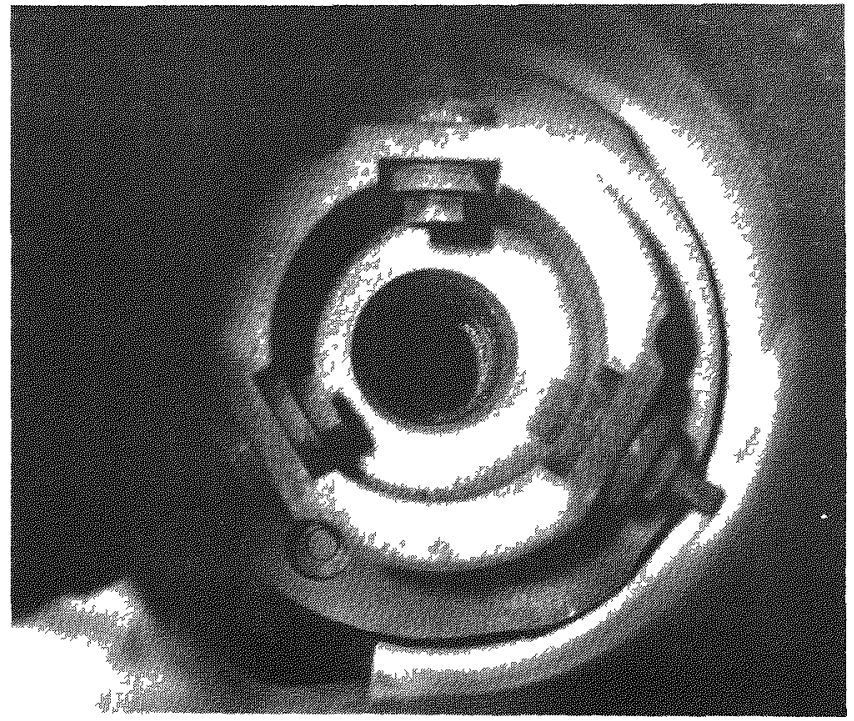

36120-4

FIGURE 21. Magnesium Metal in CRAC Cathode Tube
TABLE 9. CRAC Cell Plutonium Distribution

\begin{tabular}{|c|c|c|c|c|c|}
\hline \multirow{2}{*}{ Run } & $\begin{array}{c}\text { Product } \\
\text { (Yield) }\end{array}$ & Salt & Ceramic & $\begin{array}{c}\text { Anode } \\
\text { Heel }\end{array}$ & \multirow[t]{2}{*}{ Total } \\
\hline & \multicolumn{4}{|c|}{ (Percent Plutonium) } & \\
\hline ERNP51 & 89.6 & 3.3 & $*$ & 6.2 & 99.0 \\
\hline ERNP52 & 86.1 & 7.6 & 04 & 6.7 & 100.8 \\
\hline ERNP53 & 870 & 4.7 & 01 & 7.9 & 99.7 \\
\hline ERNP54 & 87.2 & 5.5 & 0.1 & 76 & 100.4 \\
\hline ERNP55 & 81.3 & 6.1 & 0.1 & 10.9 & 98.5 \\
\hline ERNP56 & 83.6 & 6.1 & $*$ & 10.7 & 1005 \\
\hline ERNP57 & 89.3 & 5.5 & 0.2 & 57 & 100.7 \\
\hline ERNP60 & 83.8 & 7.9 & 0.0 & 8.0 & 99.7 \\
\hline ERNP61 & 81.8 & 7.7 & $*$ & 10.1 & 99.7 \\
\hline ERNP63 & 70.0 & 18.1 & 0.7 & 9,0 & 978 \\
\hline Average & 84.0 & 73 & 0.2 & 8.3 & 99.7 \\
\hline Average** & 855 & 60 & 01 & 8.2 & 999 \\
\hline
\end{tabular}

* Ceramics were saved for reuse

**Excluding Run ERNP63.

ceramic. When this stirrer was used in Run ERNP56, it broke. The KCARS stirrer used in Run ERNP57 performed well; but after the run, it broke when it was removed from the cell. A composite stirrer was again used in Runs ERNP58 and ERNP59; however, both runs failed. 
In the remaining runs, the KCARS stirrer was used with no stirrer breakage. However, in Runs ERNP60 and ERNP61, salt between the tantalum and stainless backup cans caused the crucible to wedge in the furnace well. During the run, the crucible was positioned in the well at the wrong level, which may have affected results. When the anode basket subassembly was raised at run termination, it did not clear the salt level and became frozen in the salt.

As previously mentioned, magnesium metal condensation in Run ERNP62 prohibited ER initiation. The heat shields in the CRAC cell act as refluxing condensers for the molten salt and magnesium metal. The magnesium metal tends to condense in the gap between the anode-stirrer rod and the cathode tube. If the stirrer is removed after each run, the magnesium can be removed. However, the same KCARS stirrer was used in Runs ERNP60, ERNP61, and ERNP62 without removal between runs. This caused the magnesium metal to build up inside the cathode tube, shorting out the cell.

Connecting the stir belt to the stirrer motor was cumbersome and inconvenient. The loose stir belt often became caught on cell parts during cell head raising and lowering. Working space inside the glovebox was limited by the large cell head and counter weight.

\section{DOR Metal}

Results of casting DOR metal into anodes and subsequent electrorefining in the modified LANL cell are given in Table 10. Each anode casting required $41 / 2$ DOR product buttons and was performed by drip casting. The first casting (ACDOR15) had an 89\% casting yield, and the second casting (ACDOR16) had a 91\% casting yield. These yields are probably less than can be expected in a production operation, because the tantalum funnel was not originally designed for drip casting and the operation was performed under argon atmosphere. ER Run ERDOR02 using Casting ACDOR 15 had a yield of $89 \%$, and ER Run ERDOR03 using Casting ACDOR16 had a yield of $91 \%$. Both the casting and ER yields were calculated on a mass instead of a plutonium basis. Overall yields, casting and ER, for these two runs were 79 and $82 \%$ on a total metal basis and 81 and $83 \%$ on a plutonium basis. No operational problems were encountered in either run.

\section{DISCUSSION}

The completion criteria in the experimental plan required experiments on each cell until cell throughput and yield were estimated to within $5 \%$ at a $95 \%$ confidence level or until 12 experiments had been performed. After eight experimental runs were performed in the LANL ER cell, work was terminated. Mean process yield in the LANL cell was estimated at $75.3 \%$, which is within $7.0 \%$ of the true mean at the $95 \%$ confidence level. After seven runs had been performed in both the modified LANL ER cell and the CRAC ER cell, analyses of run data concluded that the estimated yields for both cells had met the completion criteria. The mean yield for the modified LANL cell was estimated to be $81.7 \%$, which is within $2.8 \%$ of the true mean at the $95 \%$ confidence level. The mean yield for the CRAC cell was estimated to be $86.1 \%$, which is within $3.9 \%$ of the true mean at the $95 \%$ confidence level.

The product metal assays in Tables 3,6 , and 8 were used to determine foundry acceptance criteria shown in Table 4. The neptunium assay was added to the plutonium assay for determining foundry acceptance. Several methods can be used to compare the cells for foundry acceptable product. If best assays are used, only Runs ERNP53 and ERNP54 performed in the CRAC cell produced rejected metal. However, run ERNP54 is only out of specification in gallium in its best assays and should probably not be considered as rejected. The high gallium was probably caused by anode metal being sloshed from the anode cup by excessive stirring early in the run.

If only Run ERNP53 is considered reject, the reject rate is $10 \%$ for the CRAC cell and $0 \%$ for the LANL and modified LANL cells. If average assays are used to determine reject rate, Runs LANL03 and LANL06 would be out of specification for high tungsten in the LANL cell, Run 
TABLE 10. Casting and ER of DOR Metal

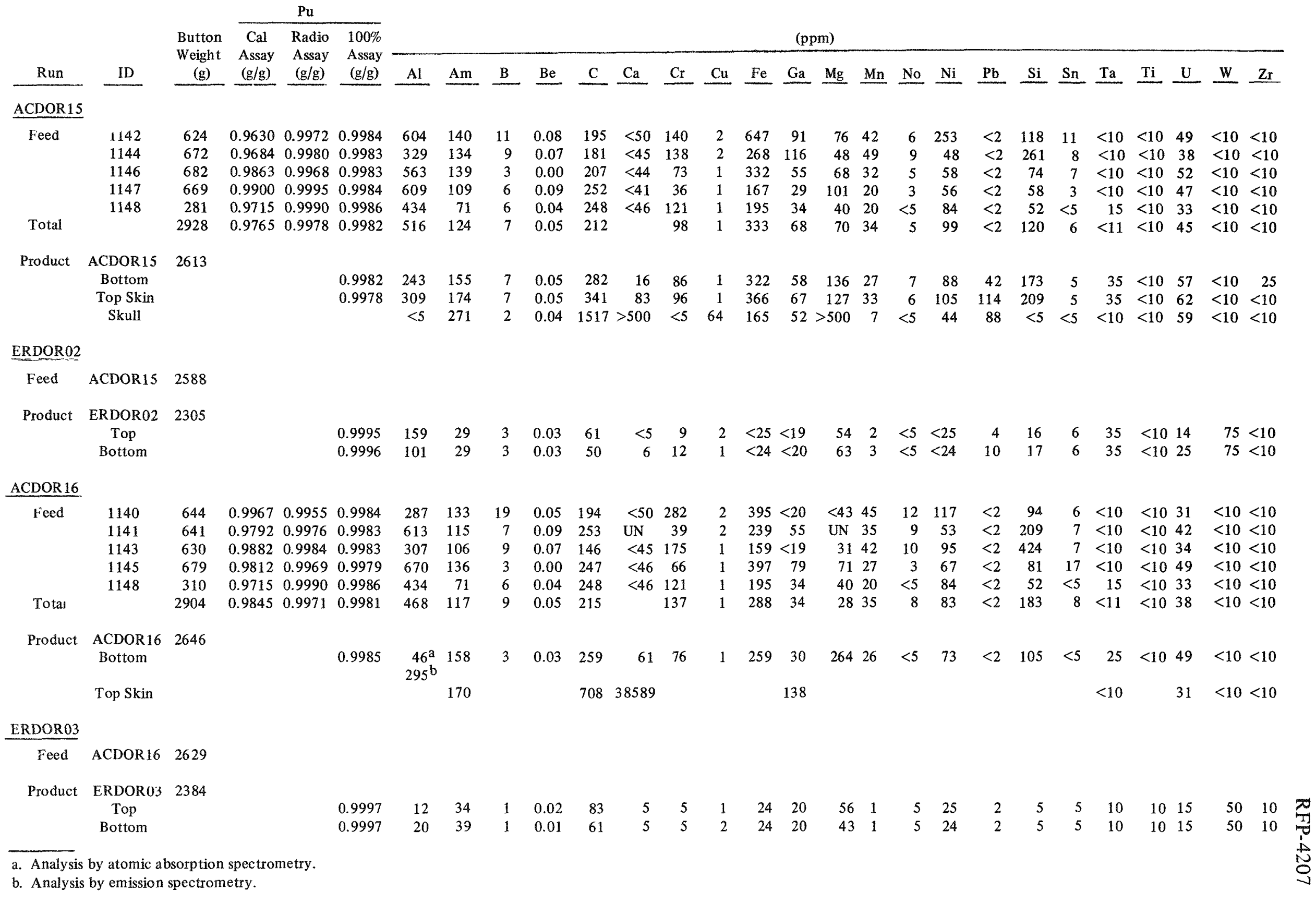




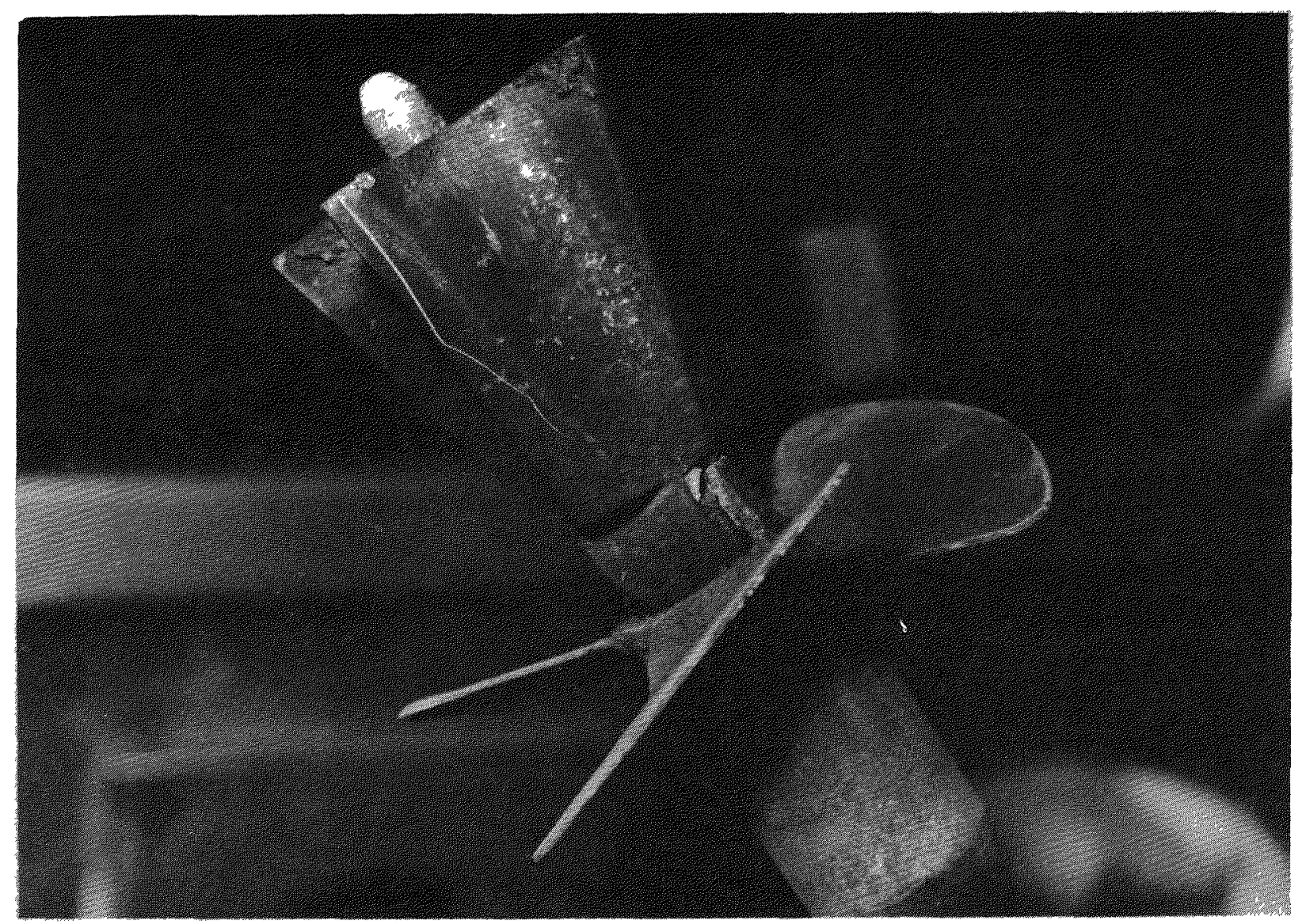

FIGURE 22. Fractured Fluted Stirrer

35342-7

ERNP09 would be out of specification for high tungsten in the modified LANL cell, and Runs ERNP51, ERNP53, ERNP54, and ERNP55 would be out of specification for high tungsten and tantalum in the CRAC cell. This method of cell comparison would result in the following reject rates: $25 \%$ for the LANL cell, $14 \%$ for the modified LANL cell, and $31 \%$ for the CRAC cell.

The product metal reject rates associated with the CRAC cell by either method indicates that this cell in its current design may not meet the criteria of foundry acceptable product. The principal reason for the poor product metal from the CRAC cell can be attributed to tantalum contamination from the tantalum impeller on the composite stirrer. Utilization of the KCARS stirrer appeared to solve this problem, but other operational concerns previously discussed overshadowed this effort.
Comparison of data in Tables 5, 7, and 9 highlights several important cell differences. The principal difference between the LANL and modified LANL cells was the increased stirring action of the KCARS stirrer. This shows up in increased yields (82.4\% for the modified LANL cell compared with $75.3 \%$ for the LANL cell) and reduced plutonium levels in the residue salt $(8.7 \%$ for the modified LANL cell compared with $13.8 \%$ for the LANL cell).

Data from the CRAC cell is not as straightforward because two stirrer designs were used and problems were encountered in implementing the KCARS stirrer. The marine prop stirrer used in Runs ERNP51 through ERNP54 in the CRAC cell produced process yields of $87.5 \%$ with $5.3 \%$ plutonium in the residue salt. Although these data reflect four runs only, analysis tends to indicate 
that better stirring was achieved in the salt phase with the marine prop verses the KCARS stirrer.

The ceramic from both the LANL and modified LANL cells had approximately the same plutonium levels of 2.6-3.0\%. This is expected because both cells were operated with the same ceramic configuration and conditions. With the tapered ceramics and heat shields, the CRAC cell had almost no plutonium $(0.1 \%)$ in the ceramic. The heat shields could have influenced this number because they eliminated residues in the top of the furnace well. With both the LANL and modified LANL cells, significant residues are deposited in the upper portions of the furnace well. These residues are typically combined with the ceramics, thus increasing the plutonium levels.

The percent of feed plutonium remaining in the anode heel reflects the effectiveness of the anode stirrer. Three different anode stirrers were used. The data show little difference between these anode stirrers. The LANL cell had $6.6 \%$ of the feed plutonium reporting to the anode heel with the malt-mixer stirrer; the modified LANL cell had $6.0 \%$ with the KCARS stirrer, and the CRAC cell had $7.1 \%$ with the fluted stirrer.

General operational data, subjective operator input, and general information for each ER cell are given in Table 11. Note that the LANL and modified

TABLE 11. ER Cell Comparison

\begin{tabular}{|c|}
\hline Parameter \\
\hline Design Complexity \\
\hline Versatility \\
\hline Component Cost \\
\hline Operation \\
\hline $\begin{array}{l}\text { A. Loading } \\
\text { B. Running } \\
\text { C. Termination } \\
\text { D. Unloading } \\
\text { E. Breakout }\end{array}$ \\
\hline $\begin{array}{c}\text { F. Rebuild } \\
\text { Seals } \\
\text { Stirrer }\end{array}$ \\
\hline $\begin{array}{l}\text { Protection of } \\
\text { Fragile Components }\end{array}$ \\
\hline Ceramic Use \\
\hline Salt Use \\
\hline Approximate Cost $(\$)$ \\
\hline Average Yields (\%) \\
\hline Approximate Throughput $(\mathrm{g} / \mathrm{hr}$ \\
\hline Product Reject Rate $(\%)$ \\
\hline Sodium Metal Observed \\
\hline
\end{tabular}

CELL

\begin{tabular}{|c|c|}
\hline LANL & Modified LANL \\
\hline Simple & Simple \\
\hline Approx. 30 parts & Approx. 28 parts \\
\hline $\begin{array}{l}\text { Readily adaptable to } \\
\text { various processes, } \\
\text { furnaces, and gloveboxes. }\end{array}$ & $\begin{array}{l}\text { Readily adaptable to } \\
\text { various process, } \\
\text { furnaces, and gloveboxes. }\end{array}$ \\
\hline
\end{tabular}

Low

Low

Easy

Easy

Moderate

Easy

Moderate to Difficult

$30-45 \mathrm{~min}$

Moderate (every run)

Moderate

None

One run

Approx. $1100 \mathrm{~g}$

Recycle not attempted $2300 \mathrm{~g}$

5,000

process,

furnaces, and gloveboxes.

\begin{tabular}{l} 
CRAC \\
\hline Moderate \\
Approx, 164 parts \\
Design specific to \\
Rocky Flats \\
furnace, ER \\
process, and \\
requires special \\
glovebox.
\end{tabular}

Moderate

Easy

Easy

Moderate

Easy

Moderate to Difficult

$30-45$ min

Easy

Moderate (every 3 rd run) Moderate

Easy

Easy

Easy

Easy

Easy

15-20 min

Difficult

Difficult

None

Good

One run
Approx. $755 \mathrm{~g}$
Recycle not attempted
$1150 \mathrm{~g}$
5,000
82
52
0
Very little in a
a few runs

Two runs Approx. $1150 \mathrm{~g}$

Recycled in one run. $1627 \mathrm{~g}$

27,000

86

52

10

Quite a lot in every run 
LANL cells had very little difference in operation. The principal differences are between the LANL cells and the CRAC cell. The CRAC cell is easier to operate, has more parts, and has higher initial cost. Throughputs were determined by dividing the average run time by the average mass of product. The run time included a 5-hour heatup, 2-hour hold, ER time, 2-hour hold, and 15-hour cooldown. The product reject rate was calculated assuming only best assays and assuming the run in the CRAC ER cell with high gallium levels was foundry grade.
To provide a cell head recommendation, a decision analysis was conducted by techniques described by Kepner and Tregoe. ${ }^{8}$ An outline of this analysis is shown in Table 12. This analysis is divided into must objectives and want objectives.

The following must objectives were determined for this analysis: the cell must perform better than the tilt-pours, produce foundry acceptable product, and be capable of safe operation. Yields were used as the single parameter of performance. As shown in Figure 1, the tilt-pour ER cell demon-

TABLE 12. ER Cell Selection

Must Objectives
Yields superior to tilt-pours
Produces foundry acceptable product
Can cell be operated safely

\begin{tabular}{l} 
Want \\
Objectives \\
High Yields \\
Low Product Reject \\
Ease of Operation \\
Low Radiation Exposure \\
Reduced Waste \& Residue \\
High Throughput \\
Ease of Maintenance \\
Low Labor Requirements \\
Low Maintenance \\
High Design Versatility \\
Low Capital Expense \\
Low Cost of Consumables \\
\hline Total
\end{tabular}

CELL

$\frac{\text { LANL }}{\text { Yes }} \frac{\text { Modified LANL }}{\text { Yes }} \frac{\text { CRAC }}{\text { Yes }}$

Yes

Yes

Not clearly determined Yes - With $\mathrm{Na}$
oxidation

Yes - With $\mathrm{Na}$
oxidation

Yes

Weighted

Weight $\quad$ Sco

Weighted
Score

$-7$

Score $\quad \begin{gathered}\text { Weighted } \\ \text { Score }\end{gathered}$

\begin{tabular}{|c|c|c|c|c|c|c|}
\hline 10 & 8 & 80 & 9 & 90 & 10 & 100 \\
\hline 10 & 10 & 100 & 10 & 100 & 7 & 70 \\
\hline 9 & 6 & 54 & 8 & 72 & 10 & 90 \\
\hline 8 & 6 & 48 & 6 & 48 & 10 & 80 \\
\hline 8 & 5 & 40 & 7 & 56 & 10 & 80 \\
\hline 7 & 6 & 42 & 10 & 70 & 10 & 70 \\
\hline 7 & 10 & 70 & 10 & 70 & 5 & 35 \\
\hline 7 & 7 & 49 & 7 & 49 & 10 & 70 \\
\hline 7 & 7 & 49 & 7 & 49 & 10 & 70 \\
\hline 5 & 10 & 50 & 10 & 50 & 2 & 10 \\
\hline 4 & 10 & 40 & 10 & 40 & 3 & 12 \\
\hline 3 & 10 & 30 & 10 & 30 & 7 & 21 \\
\hline & & 652 & & 724 & & 708 \\
\hline
\end{tabular}

POTENTIAL RISKS

\section{LANL and Modified LANL Cells}

1. Radiation exposure coulu become an overriding concern.

2. Excessive rough handling of fragile components in production.

CRAC Cell

1. Problems with product reject rate not solved.

2. Cell could develop severe maintenance problems.

$\begin{array}{cc}\text { Probability } & \begin{array}{c}\text { Seriousness } \\ \text { if it occurs }\end{array} \\ \text { Medium } & \text { Medium } \\ \text { High } & \text { Medium }\end{array}$

Low High


strated average yields of $64 \%$. All cells evaluated had significantly higher average yields. The CRAC cell had a high reject rate in comparison with the other cells and thus did not meet the criteria of foundry acceptable product.

Regarding safe operation, the LANL cell has been operated safely at Los Alamos for more than 20 years but does produce significant amounts of pyrophoric sodium. If this sodium is oxidized properly at the ER cell, no safety problem is created. This can be accomplished by purging the furnace with an oxidizing atmosphere after cooldown or by having an oxidizing atmosphere in the glovebox. The modified LANL cell had a small amount of sodium oxidation in a few runs. No sodium oxidation was observed in the CRAC cell.

The overall score in Table 12 shows that the modified LANL cell is currently the cell of choice. However, if the CRAC cell's product reject rate decreased, it will have an overall score higher than the modified LANL cell and thus be the preferred cell. The modified LANL cell has two risks considered to have medium to high probability: greater radiation exposure and unshielded fragile components. If radiation exposure becomes an overriding concern, the CRAC cell could be implemented and the modified LANL cell (because of its low cost and versatility) could be used for other pyrochemical processes. If fragile components in the modified LANL cell cannot survive in a Rocky Flats production environment, those components may need replacing more regularly, thus increasing waste and residue production.

The CRAC cell has two risks considered to have low probability: product reject rate and maintainability. Runs ERNP56, ERNP57, ERNP60, ERNP61, and ERNP63 in the CRAC cell using the KCARS stirrer indicate that the product reject problem can be solved; but additional problems were encountered in the cell with the KCARS stirrer. These problems were not factored into Table 12 because the KCARS stirrer was retrofitted to the CRAC cell and was not an optimum design. A stirrer properly designed for the CRAC cell must be evaluated and the values in Table 12 redetermined. The risk of severe maintenance problems with the CRAC cell should be addressed in further development efforts.

\section{RECOMMENDATIONS}

A principal objective of this task was to provide a cell head recommendation for implementation by the Plutonium Recovery Project. On February 27, 1987, the modified LANL cell was recommended as the preferred cell head. Subsequently, additional runs were performed in the CRAC cell to determine whether product purity would improve by implementing an all-ceramic stirrer such as the KCARS. These runs resulted in foundry acceptable product, but additional operational problems were encountered, i.e., anode cup breakage and magnesium shorting. These problems indicate that additional CRAC cell development work is required. Therefore, the modified LANL cell remains the recommended cell head.

In addition to a cell head recommendation, this work indicated the following important areas for focusing further efforts:

1. Development of stirrers or techniques to improve stirring in the salt phase, thereby decreasing the diffusion boundary layer and increasing operational current.

2. Development of furnace well designs that ensure an adequate heat zone. This is especially critical for other pyrometallurgical processes that require longer crucibles, such as DOR.

3. Development of furnace well designs that minimize cell head size, thus decreasing the size and weight.

4. Further development of the CRAC cell as warranted by the positive features demonstrated in this cell.

5. Upgrading, where possible, of the modified LANL cell until a superior cell is developed or demonstrated.

6. Development of a direct drive between the stirrer and motor for the modified LANL and CRAC cells. 


\section{REFERENCES}

1. J. L. Long and R. D. Schweikhardt, Plutonium Electrorefining at Rocky Flats, RFP-871, Dow Chemical Company, Rocky Flats Plant, Golden, CO, April 17, 1967.

2. L. J. Mullins, J. A. Leary, and C. W. Bjorklund, Large Scale Preparation of High Purity Plutonium Metal by Electrorefining, LAMS2441, Los Alamos Scientific Laboratory, Los Alamos, NM, September 13, 1960.

3. L. J. Mullins, J. A. Leary, A. N. Morgan, and W. J. Maraman, Plutonium Electrorefining, LA-2666, Los Alamos Scientific Laboratory, Los Alamos, NM, June 22, 1962.

4. L. J. Mullins, A. N. Morgan, S. A. Apgar, III, and D. C. Christensen, Six-Kilogram Scale
Electrorefining of Plutonium Metal,

LA-9469-MS, Los Alamos Scientific Laboratory, Los Alamos, NM, September 1982.

5. L. J. Mullins and A. N. Morgan, A Review of Operating Experience at the Los Alamos Plutonium Electrorefining Facility, 1963-1977, LA-8943, Los Alamos Scientific Laboratory, Los Alamos, NM, December 1981.

6. J. Bockris and A. K. N. Reddy, Modern Electrochemistry, Plenum Press, New York, NY, 1970.

7. L. J. Mullins, et al., "Plutonium Electrorefining Cell," U. S. Patent 3,098,028, July 16, 1963.

8. C. H. Kepner and B. B. Tregoe, The New Rational Manager, Kepner-Tregoe Inc., Princeton, NJ, 1981. 